\title{
A structural, phylogenetic, and functional study of 15.5-kD/Snu13 protein binding on U3 small nucleolar RNA
}

\author{
NATHALIE MARMIER-GOURRIER, ${ }^{1}$ ANTOINE CLÉRY, ${ }^{1}$ VÉRONIQUE SENTY-SÉGAULT, BRUNO CHARPENTIER, \\ FLORENCE SCHLOTTER, FABRICE LECLERC, RÉGIS FOURNIER, and CHRISTIANE BRANLANT \\ Laboratoire de Maturation des ARN et Enzymologie Moléculaire, UMR 7567 UHP-CNRS, Université Henri Poincaré Nancy 1, 54506 \\ Vandoeuvre-Lès-Nancy cedex, France
}

\begin{abstract}
The 15.5-kD protein and its yeast homolog Snu13p bind U4 snRNA, U3 snoRNA, and the C/D box snoRNAs. In U4 snRNA, they associate with a helix-bulge-helix (K-turn) structure. U3 snoRNA contains two conserved pairs of boxes, $C^{\prime} / D$ and B/C, which were both expected to bind the $15.5-\mathrm{kD} / \mathrm{Snu} 13$ protein. Only binding to the $\mathrm{B} / \mathrm{C}$ motif was experimentally demonstrated. Here, by chemical probing of in vitro reconstituted RNA/protein complexes, we demonstrate the independent binding of the 15.5$\mathrm{kD} / \mathrm{Snu} 13$ protein to each of the two motifs. Due to a highly reduced stem I (1 bp), the K-turn structure is not formed in the naked B/C motif. However, gel-shift experiments revealed a higher affinity of Snu13p for the B/C motif, compared to the $C^{\prime} / D$ motif. A phylogenetic analysis of U3 snoRNA, coupled with an analysis of Snu13p affinity for variant yeast $C^{\prime} / D$ and B/C motifs, and a study of the functionality of a truncated yeast $U 3$ snoRNA carrying base substitutions in the $C^{\prime} / D$ and $B / C$ motifs, revealed that conservation of the identities of residues 2 and 3 in the B/C K-turn is more important for Snu13p binding and U3 snoRNA function, than conservation of the identities of corresponding residues in the $C^{\prime} / D$ K-turn. This suggests that binding of Snu13p to K-turns with a very short helix I imposes sequence constraints in the bulge. Altogether, the data demonstrate the strong importance of the binding of the $15.5-\mathrm{kD} /$ Snu13 protein to the $C^{\prime} / \mathrm{D}$ and $\mathrm{B} / \mathrm{C}$ motifs for both U3 snoRNP assembly and activity.
\end{abstract}

Keywords: U3 snoRNA; 15.5-kD/Snu13 protein; snoRNP, RNA-protein interaction; K-turn structure; RNA evolution

\section{INTRODUCTION}

The large ribosomal RNAs (17S/18S, 5.8S, and 25S/28S rRNAs) of eucaryotes are produced from a long precursor (pre-rRNA) by an ordered series of cleavages (for review, see Venema and Tollervey 1999). Nucleotide modifications (pseudouridylations and 2'-O-methylations) are generated at the same time (for review, see Terns and Terns 2002). Cleavage steps are dependent upon small nucleolar RNAs (snoRNAs), which are associated with proteins to form snoRNPs (for review, see Terns and Terns 2002). One of them, U3 snoRNA, plays a crucial role in cleavages at sites A0, A1, and A2 for Saccharomyces cerevisiae (for review, see

\footnotetext{
${ }^{1}$ These authors participated equally to this work.

Reprint requests to: Christiane Branlant, Laboratoire de Maturation des ARN et Enzymologie Moléculaire, UMR 7567 UHP-CNRS, Université Henri Poincaré Nancy 1, Boulevard des Aiguillettes, 54506 VandoeuvreLès-Nancy cedex, France; e-mail: christiane.branlant@maem.uhp-nancy.fr; fax: 33383684307 .

Article and publication are at http://www.rnajournal.org/cgi/doi/ 10.1261/rna.2130503.
}

Venema and Tollervey 1999) and A0, 1, 2, and 3 for Xenopus laevis (Borovjagin and Gerbi 1999, 2001). Positions of pseudouridylation and 2'-O-methylation are defined by base pair interactions of the pre-rRNA with guide RNAs (H/ACA snoRNAs for pseudouridylations and C/D box snoRNAs for 2'-O-methylations; Cavaille et al. 1996; Ganot et al. 1997; Ni et al. 1997). The $5^{\prime}$-terminal domain of U3 snoRNA interacts with the pre-rRNA $5^{\prime}$-ETS and 17S/18S regions (Beltrame and Tollervey 1992, 1995; Beltrame et al. 1994; Brule et al. 1996; Hughes 1996; Mereau et al. 1997; Hartshorne and Toyofuku 1999; Borovjagin and Gerbi 2000, 2001). Its 3' domain contains the highly conserved $\mathrm{C}^{\prime} / \mathrm{D}$ and B/C box pairs (Wise and Weiner 1980; Hughes et al. 1987; Tycowski et al. 1993). It binds the U3 snoRNP core proteins (Parker and Steitz 1987; Jeppesen et al. 1988; Mereau et al. 1997; Samarsky and Fournier 1998), in particular the Snu13 (yeast)/15.5-kD (human) protein (Watkins et al. 2000, 2002), first identified as a component of the spliceosomal (U4/U6-U5) tri-snRNP (Stevens and Abelson 1999; Gottschalk et al. 1999; Nottrott et al. 1999). As evidenced by X-ray analysis in the spliceosomal tri-snRNP 
(Vidovic et al. 2000), the Snu13/15.5-kD protein interacts with a two-stranded helix I-bulge-helix II motif of U4 snRNA (Nottrott et al. 1999; Vidovic et al. 2000). Helix I contains canonical base pairs, whereas helix II contains two canonical GC base pairs and two GA and AG sheared pairs (Vidovic et al. 2000). Only residue U31 of the NPuU bulged sequence is not stacked with the helices and is located in a nucleotide binding pocket of the protein (Vidovic et al. 2000). This peculiar RNA motif was called a kink-turn (K-turn) structure, because of the kink of about $120^{\circ}$ imposed to the phosphodiester backbone. Later on, several K-turn structures were identified in ribosomal RNAs (Klein et al. 2001). As we found that the C/D box snoRNAs also bind the 15.5-kD protein (Watkins et al. 2000), the C/D box pairs of these snoRNAs were proposed to form a K-turn structure similar to that in U4 snRNA (Watkins et al. 2000). This hypothesis is sustained by data of mutational analyses of the C/D motif of U14 snoRNA (Watkins et al. 2000, 2002). In addition to the C/D motif, C/D guide snoRNAs also contain a $\mathrm{C}^{\prime} / \mathrm{D}^{\prime}$ motif, that can form a K-turn structure with a protruding $\mathrm{U}$ residue. Although this $\mathrm{C}^{\prime} / \mathrm{D}^{\prime}$ motif was also expected to bind the Snu13/15.5-kD protein, recent data suggest that this is not the case (Cahill et al. 2002; Szewczak et al. 2002). Concerning U3 snoRNA, binding of the Snu13/15.5-kD protein was only experimentally demonstrated for the B/C motif (Granneman et al. 2002). The $\mathrm{C}^{\prime} / \mathrm{D}$ motif can form a K-turn structure (Watkins et al. 2000), however, this K-turn structure shows deviation compared to the consensus motif found for the C/D motif of guide snoRNAs: the extruded $\mathrm{U}$ residue expected to interact with the protein pocket is replaced by a $\mathrm{G}$ residue in human U3 snoRNA and the purine residue $5^{\prime}$ to the extruded $\mathrm{U}$ residue is replaced by an $\mathrm{U}$ residue in $S$. cerevisiae $\mathrm{U} 3$ snoRNA (Watkins et al. 2000). Nevertheless, like the C/D motif of C/D box snoRNAs, the C'/D motif of U3 snoRNA was found to be responsible for nucleolar localization of U3 snoRNA (Lange et al. 1998; for review, see Terns and Terns 2002), and it is well established that binding of the Snu13/15.5-kD, Nop56, Nop58, and Nop1 protein set to the C/D box motif of snoRNAs is important for the nucleolar localization of these RNAs (for review, see Terns and Terns 2002). This was an indication that the U3 C'/D motif likely binds this set of proteins. However, it was important to obtain an experimental demonstration of this binding.

Here, we used chemical probing to get this direct demonstration for both human and S. cerevisiae U3 snoRNAs. Having shown that the Snu13/15.5-kD protein binds both the $C^{\prime} / D$ and $B / C$ box pairs, we then evaluated the relative affinities of Snu13p for these two motifs by gel-shift experiments. As the $\mathrm{B} / \mathrm{C}$ motif was found to have the highest affinity, we tried to identify the determinants for this higher affinity by gel-shift assays and site-directed mutagenesis of in vitro produced RNAs. The effects of point mutations in the $\mathrm{C}^{\prime} / \mathrm{D}$ and $\mathrm{B} / \mathrm{C}$ motifs were also tested on the stability and the functionality of U3 snoRNA in vivo, using the $S$. cerevisiae JH84 strain (Hughes and Ares 1991). The results obtained are discussed taking into account a phylogenetic analysis of the $\mathrm{C}^{\prime} / \mathrm{D}$ and $\mathrm{B} / \mathrm{C}$ motifs, the possible roles of the conserved features of these motifs for Snu13/15.5-kD binding and for assembly of the other U3 snoRNP proteins.

\section{RESULTS}

\section{Chemical probing of the $15.5-\mathrm{kD} / \mathrm{hU} 3$ RNA complex}

Chemical probing was used for experimental analysis of human U3 snoRNA secondary structure and identification of protections generated by binding of the recombinant $15.5-\mathrm{kD}$ protein. The hU3 transcript used in the experiments is described in Materials and Methods. Based on gel-shift experiments (not shown), a 1/3300 [hU3]/[15.5$\mathrm{kD}$ ] ratio was selected for footprinting experiments. Three chemical probes were used: dimethyl sulfate (DMS), that methylates RNA at N1-A, N3-C, and N7-G positions, 1-cyclohexhyl-3-(2-morpholinoethyl-) carbodiimide metho- $p$ toluene sulfonate (CMCT), which alkylates RNA at N3-U and N1-G positions, and kethoxal that modifies $\mathrm{G}$ at the $\mathrm{N} 1$ and N3 positions. Naked RNA and the RNA/protein complex were modified in the same conditions and positions of modifications were identified by extension with reverse transcriptase of oligonucleotide RT-hU3 complementary to the $3^{\prime}$ extremity of the hU3 transcript. Reproducible results were obtained in the course of several experiments and an example of cDNA fractionation is illustrated in Figure 1A.

The data obtained for the naked hU3 transcript confirmed the previously proposed (Parker and Steitz 1987) stem-loop structures 1 and 2 and helix 5 (Fig. 1B). The limited accessibility to chemical reagents of the $\mathrm{C}^{\prime}$ box suggested that the helix-loop-helix structure, proposed to be required for binding of the $15.5-\mathrm{kD}$ protein, was present in some of the naked hU3 molecules (Watkins et al. 2000) (see the low level of modification of AAGA 84 to 87 and the absence of modification of UCU 208 to 210 in Fig. 1B). The $5^{\prime}$ part of box $\mathrm{B}$ and the $3^{\prime}$ border of box $\mathrm{C}$ were not modified, revealing the formation in naked RNA of a part of the helix ІІв/C of the K-turn structure proposed to bind the 15.5-kD protein (Watkins et al. 2000, 2002; Fig. 1B). However, as evidenced by the strong reactivity of residue U158, the second very short helix IB/C of this K-turn structure was not formed in the naked RNA. Hence, the B/C helix-loophelix structure does not preexist in the naked transcript (Fig. 1B,C). Surprisingly, in this transcript, the segment 190-193, previously proposed to be involved in helix 3 formation (Parker and Steitz 1987; Granneman et al. 2002), was single-stranded, and its partner sequence in helix 3 (segment 168-171) was not modified (Fig. 1B). One possible explanation is a base pair interaction between the $5^{\prime}$ terminal sequence of the transcript (AAG) and the segment 168-171 (Fig. 1B). Due to the absence of cap structure, this 
interaction may be stronger in the transcript compared to the authentic RNA.

Protections of the $\mathrm{C}^{\prime} / \mathrm{D}$ box pair in the RNA/protein complex were compatible with binding of the $15.5-\mathrm{kD}$ protein to the previously proposed K-turn structure (Watkins et al. 2000). Protection of the bulge sequence likely resulted from direct protein interaction, whereas protection of helix IIC'/D might result either from a direct RNA/protein interaction, or a stabilization of the helix in the complex. Protections in the B/C motif (positions 113-117 in box B and positions $156-163$ in box $C$ ) were also in agreement with recognition of the previously proposed K-turn structure by the protein (Watkins et al. 2000, 2002; Fig. 1). Here also, protection of the internal loop likely resulted from direct protein binding, whereas protection of helix I might reflect either a direct $\mathrm{RNA}$ /protein contact or the formation of helix IB/C, which was absent in naked RNA. Interestingly, residue $\mathrm{C} 116$ juxtaposed at one extremity of helix IB/C, became more sensitive in the complex compared to the naked RNA. The segment 190-193 and residue G106 were also protected in the complex (Fig. 1C). This may be explained by the presence of GA and AG pairs in this area of human U3 snoRNA, which may form an additional $15.5-\mathrm{kD}$ recognition motif, that was occupied by the protein at the high protein/RNA ratio used in these assays.

\section{Chemical probing of the Snu13p/ yU3A $\Delta 2,3,4$ complex}

S. cerevisiae U3 snoRNA is larger than vertebrate U3 snoRNA (333 nt instead of 197-219 nt). As we and others (Mereau et al. 1997; Samarsky and Fournier 1998) previously showed that yeast U3 snoRNA deleted from stemloop structures 2,3 , and/or 4 is functional in vivo, we probed the binding sites of Snu13p on the $\mathrm{C}^{\prime} / \mathrm{D}$ and $\mathrm{B} / \mathrm{C}$ motifs of a truncated version of yeast U3 RNA. In this truncated yU3A $\Delta 2,3,4$ RNA, stem-loop structures 2, 3, and 4 were deleted, and boxes $\mathrm{B}$ and $\mathrm{C}$ were expected to be in a terminal loop (Fig. 2B). The functionality of RNA $\mathrm{yU} 3 \mathrm{~A} \Delta 2,3,4$ was verified in the $S$. cerevisiae JH84 strain, in conditions where none of the two chromosomal U3 genes were expressed (Hughes and Ares 1991; Mereau et al. 1997). Growth on YPD plates at $20^{\circ} \mathrm{C}, 30^{\circ} \mathrm{C}$ and $37^{\circ} \mathrm{C}$ was only very slightly affected by the truncations (Fig. $6 \mathrm{C}$, see below).

The naked yU3A $\Delta 2,3,4$ RNA and complexes formed with recombinant Snu13p at an [RNA]/[protein] ratio of 1/3000 were probed with DMS, CMCT, and kethoxal. Experiments were repeated three times, and a representative example of the data is shown in Figure 2A. In naked RNA, the data are in agreement with formation, in some of the molecules, of the helices IC'/D and IIC'/D of the K-turn structure expected to be recognized by Snu13p (see the low level of modification of segment 75-86 containing the $\mathrm{C}^{\prime}$ box in Fig. 2A). Similarly, the low level of modification of the AG (110-111) and $\mathrm{CU}$ (128-129) dinucleotides in boxes B and C, respec-

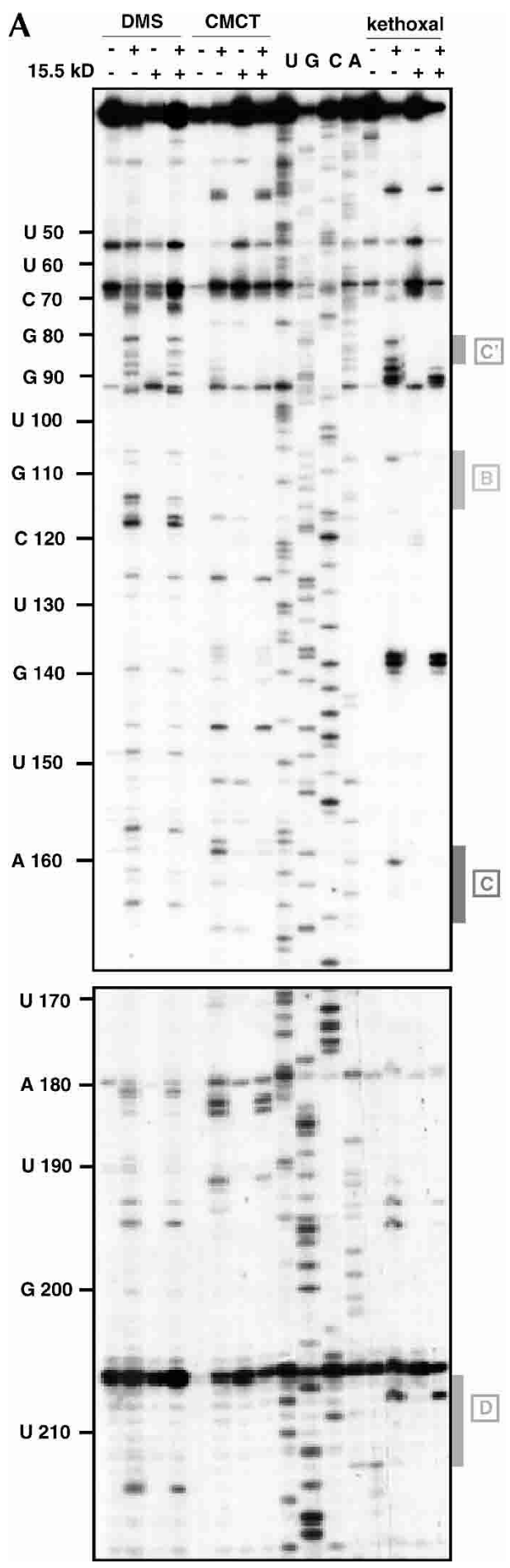

FIGURE 1. (Continued on next page)

tively, revealed the formation of a part of the helix IIв/C of the K-turn structure proposed to be recognized by Snu13p (Fig. 2A,B). However, based on the strong reactivity of residues 114 to 124 this K-turn structure was not formed in the naked RNA.

In the RNA/protein complex, protection of box $\mathrm{C}^{\prime}$ was 
B

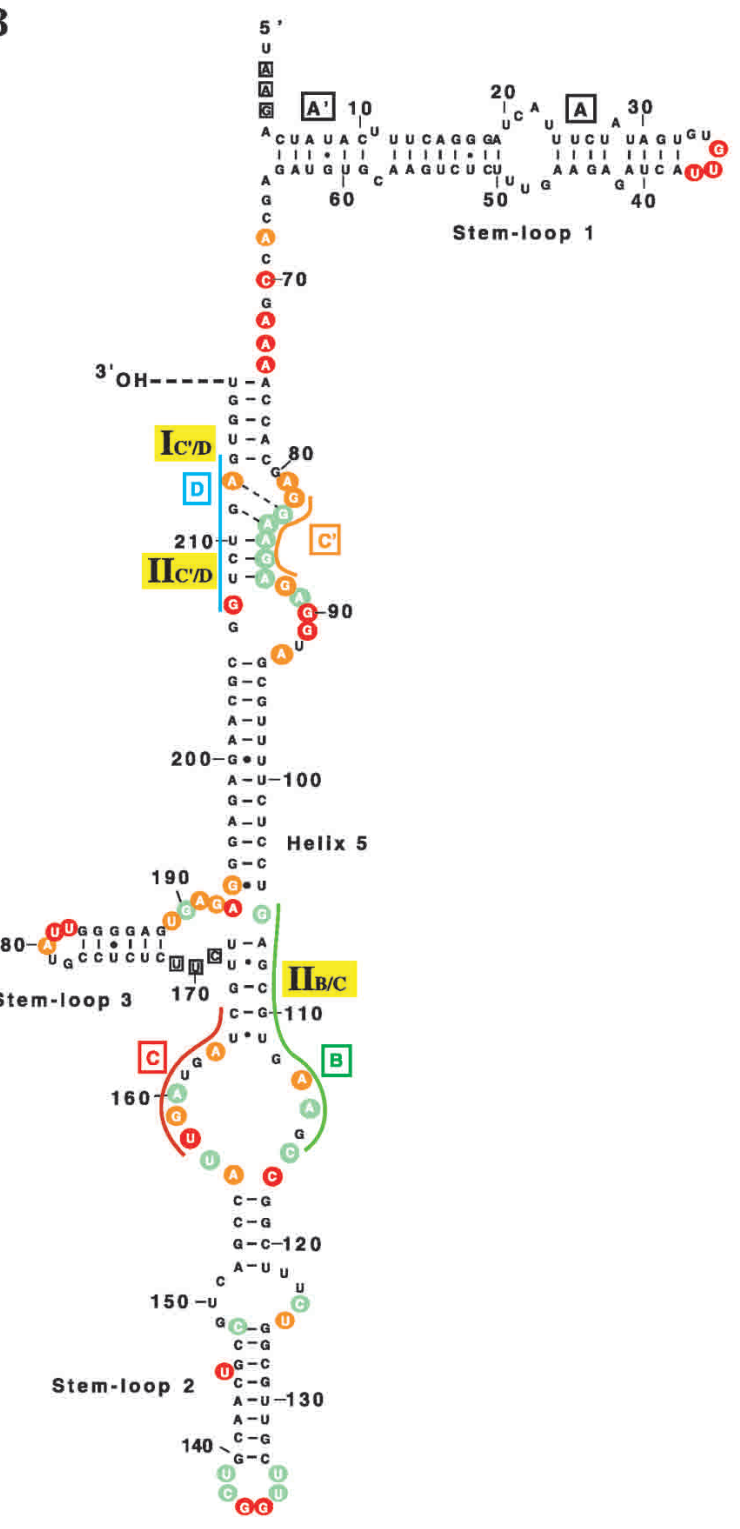

C

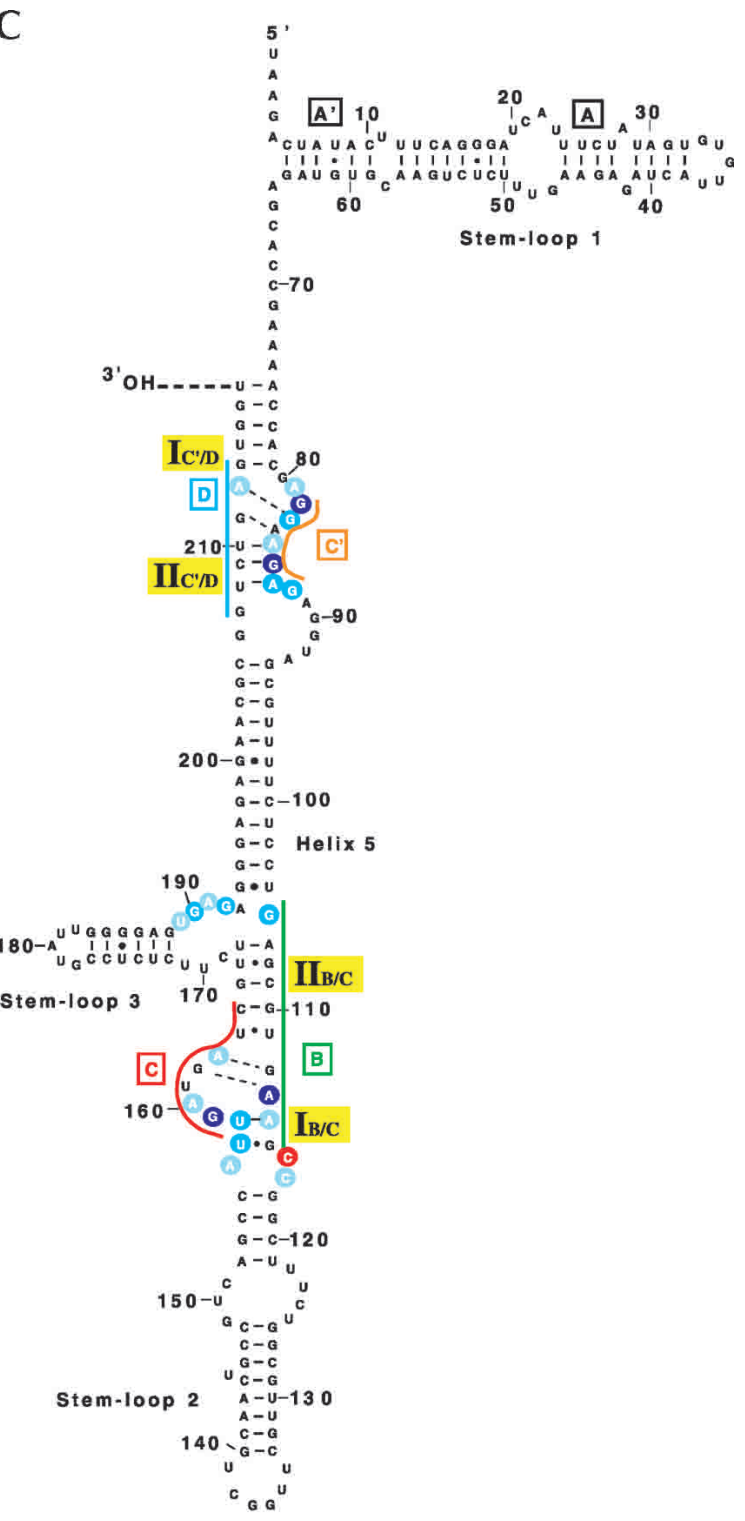

FIGURE 1. Structural analysis of the $15.5 \mathrm{kD} / \mathrm{hU} 3$ complex. (A) Primer extension analysis of the chemically modified hU3 RNA and hU3 RNA/15.5 kD protein complex. Fifty picomoles of recombinant $15.5 \mathrm{kD}$ protein were incubated with about 15 fmoles of in vitro transcribed hU3 RNA, using the conditions described in Materials and Methods. The free RNA $(-15.5 \mathrm{kD})$ and the RNA/protein complex $(+15.5 \mathrm{kD})$ were subjected to the chemical reagents indicated at the top of the autoradiogram (DMS, CMCT, and kethoxal), using the conditions described in Materials and Methods. Lanes marked by - are control experiments performed on the RNA or RNA/protein complex in the absence of any chemical reagent. The $5^{\prime}$-end labeled oligonucleotide RT-hU3 was the primer for reverse transcription. The synthesized cDNAs were fractionated by electrophoresis on a $7 \%$ sequencing gel. Lanes $U, G, C$, and $A$ correspond to a sequence ladder made with the same oligonucleotide. Nucleotide positions in hU3 RNA are indicated on the left of the panel. Boxes $C^{\prime}, \mathrm{B}, \mathrm{C}$, and D are shown on the right of the autoradiogram. In $(B)$ and $(C)$, the chemical modifications observed for the naked hU3 RNA $(B)$ and the protections observed in the hU3 RNA/15.5-kD complex $(C)$ are represented on a revised version of the secondary structure previously proposed for the human U3 snoRNA (Parker and Steitz 1987). The conserved $\mathrm{B}, \mathrm{C}, \mathrm{C}^{\prime}$, and $\mathrm{D}$ boxes are indicated. The helices IC'/D, IIC'/D, Iв/C, and IIB/C of the K-turn motifs are also indicated. Helix numbering from 1 to 5 is as for yeast U3 snoRNA (Segault et al. 1992). In (B), chemically modified residues are in colored circles: red, orange, and green circles represent strong, medium, and low levels of modification, respectively. The protected sequence CUU (169 to 171) and its possible partner sequence at the $5^{\prime}$ extremity of the RNA are shown by squared residues. In $(C)$, nucleotides protected in the complex compared to naked RNA are in blue circles: the darkness of the blue reflects the level of protection. Residues with a reinforced reactivity in the complex are shown in red circles.

low compared to protection of the $\mathrm{B}$ and $\mathrm{C}$ boxes. No information was available on box $\mathrm{D}$, as it was covered by the RT-yU3 oligonucleotide used for the primer extension analysis. The $\mathrm{C}^{\prime}$ sequences, respectively located in the lateral loop and in helix IIC'/D of the K-turn, were protected (Fig. $4 \mathrm{C}$, see below). Here, again, protection of the helix (GAG 

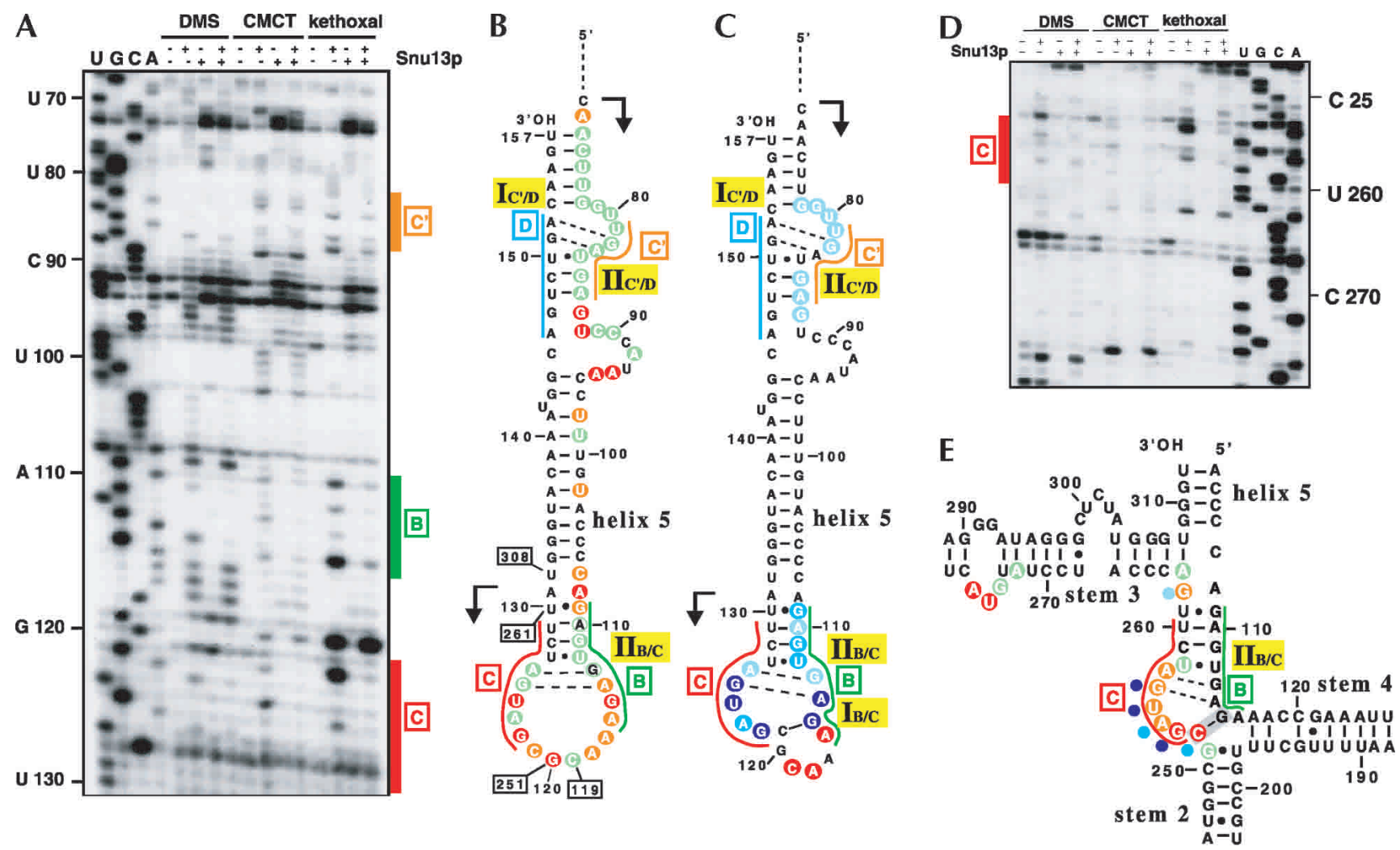

FIGURE 2. Structural analysis of the Snu13p/yU3A $\Delta 2,3,4$ complex. (A) Primer extension analysis of the chemically modified yU3A $\Delta 2,3,4$ RNA and yU3A $\Delta 2,3,4 \mathrm{RNA} /$ Snu13p complex. Sixty picomoles of recombinant Snu13p were incubated with about 20 fmoles of in vitro transcribed yU3A $\Delta 2,3,4$ RNA, in the conditions described in Materials and Methods. The free RNA (-Snu13p) and the RNA/protein complex (+Snu13p) were subjected to the chemical reagents indicated at the top of the autoradiogram (same legend as in Fig. 1A). The $5^{\prime}$-end labeled oligonucleotide RT-yU3 was used for primer extension analyses and sequence analysis (lanes $U, G, C$, and $A$ ). The synthesized cDNAs were fractionated by electrophoresis on a 7\% sequencing gel. Nucleotide positions in yU3A $\Delta 2,3,4$ RNA are indicated on the left of the panel. Boxes $C^{\prime}, B$, and $C$ are shown on the right of the autoradiogram. In $(B)$ and $(C)$, the chemical modifications observed on the naked yU3A $\Delta 2,3,4$ RNA $(B)$ and the protection observed in the yU3A $\Delta 2,3,4 /$ Snu13p complex $(C)$ are represented on the deduced secondary structure of yU3A $\Delta 2,3,4$ RNA. Positions of residues in the entire $S$. cerevisiae U3A snoRNA are indicated in black squares. The broken arrows delimit the part of the RNA yU3A $\Delta 2,3,4$ (positions 72 to 130 ), whose analysis is shown in $(A)$. The helices IC'/D, IIC'/D, IB/C, and IIB/C of the K-turn structures are indicated when they are expected to be present. In $(B)$, nucleotides circled in red, orange, and green were modified at high, medium, and low levels, respectively. In $(C)$, the residues protected in the RNA/protein complex are in blue circles. The darkness of the blue circles reflects the level of protection. Nucleotides with an increased reactivity in the complex are in red circles. In $(D), 60$ pmoles of the recombinant Snu13p were incubated with about 20 fmoles of yU3A RNA in the presence $2 \mu \mathrm{g}$ of yeast tRNAs, using the conditions described in Materials and Methods. The protein complex $(+$ Snu13p) and the free RNA (-Snu13p) were treated with the chemical reagents (same legend as in Fig. 1A). Primer extension analyses and sequence analysis (lanes $U, G, C$, and $A$ ) were performed with oligonucleotide RT-yU3. Positions of residues in the yeast U3A snoRNA are indicated on the right of the autoradiogram, box C is indicated on the left. In $(E)$, the results obtained in $(D)$ are schematically represented on the portion of the yeast U3A snoRNA secondary structure, corresponding to boxes B and C. Nucleotides modified in free RNA are circled and the color of the circles reflects the level of modification (same color code as in $[B]$ and $[C]$ ). Protections in the complex are indicated by blue dots. The darkness of the blue reflects the level of protection. The $\mathrm{C}-\mathrm{G}$ pair 115-252, expected to be formed upon protein binding, is indicated in a rectangle.

85-87) might result either from its stabilization or from direct RNA/protein contact. For the B/C motif, almost all residues of box $B$ and the GAUGA sequences of box $C$ were protected (Fig. 2C), and the highest degree of protection was found in the bulge sequence. Interestingly, the AAACG terminal loop (segment 116 to 120) was more strongly modified in the complex than in the naked RNA (Fig. 2C), showing that this sequence remained highly accessible in the presence of the protein. The stronger protection of the $\mathrm{B} / \mathrm{C}$ motif, compared to the $\mathrm{C}^{\prime} / \mathrm{D}$ motif, suggested a higher affinity of Snu13p for the B/C pair than for the $C^{\prime} / D$ pair.
By repeating the probing experiments on a full-length yeast U3 snoRNA transcript, we showed that the same residues of box $\mathrm{C}$ were protected in the full-length RNA as in the truncated RNA (Fig. 2D,E). Up to now, no complete experimentally based secondary structure model has been proposed for the four-way junction between helix 5 and stem-loop structures 2, 3, and 4 of $S$. cerevisiae U3 snoRNA (Mereau et al. 1997). Taking into account the probing data in Figure 2 and previous probing data (Mereau et al. 1997), we propose a structure including the K-turn motif recognized by Snu13p (Fig. 2E). Note that the G115-C252 base 
A

C/D

\begin{tabular}{|c|c|c|c|c|c|c|c|c|c|c|}
\hline 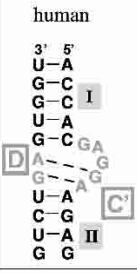 & 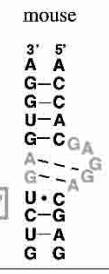 & 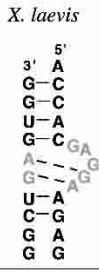 & 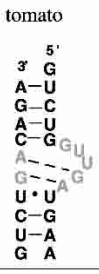 & 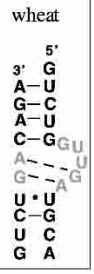 & 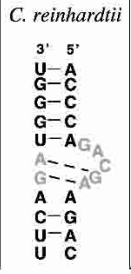 & 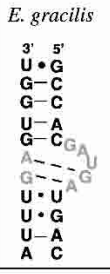 & 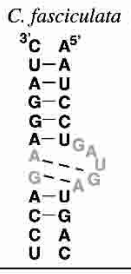 & 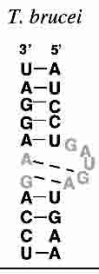 & 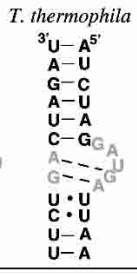 & \\
\hline S. cerevisae $I$ & H. wingei & K. $b$ & K. $d$ & K. $m$ var. & K. $m$ var. & P. $a$ & P. $g$ & P.p & P.s & S. pombe \\
\hline 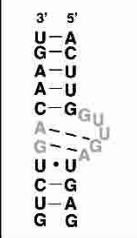 & 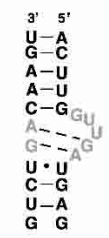 & 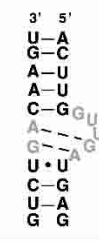 & $\begin{array}{l}3^{\prime} 5^{\prime} \\
U-A \\
G-C \\
A-U \\
A-U \\
C-G_{G} \\
A=- \\
G=- \\
U \cdot U^{-A} \\
C-G \\
U-A \\
G-A\end{array}$ & 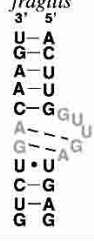 & 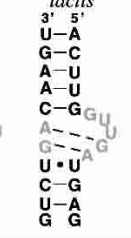 & 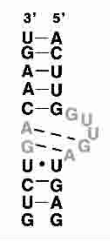 & 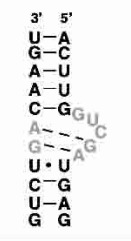 & 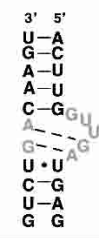 & 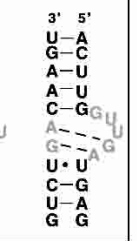 & 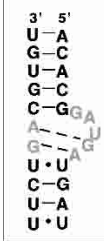 \\
\hline
\end{tabular}

B

\section{B/C}

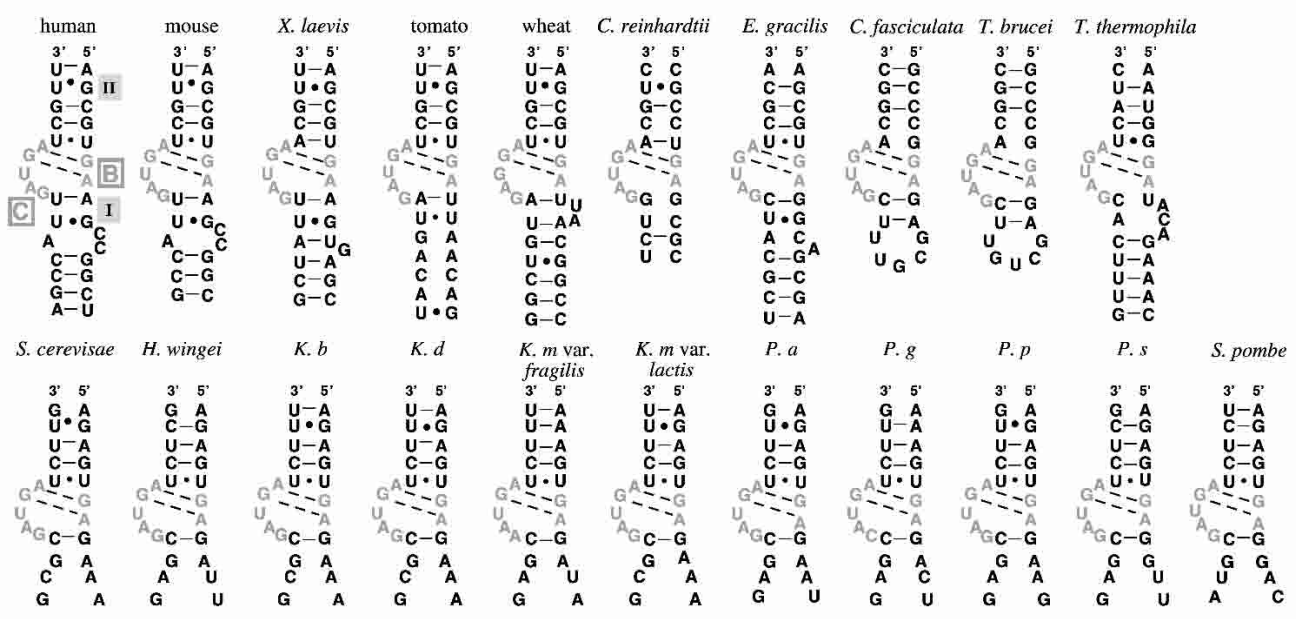

C
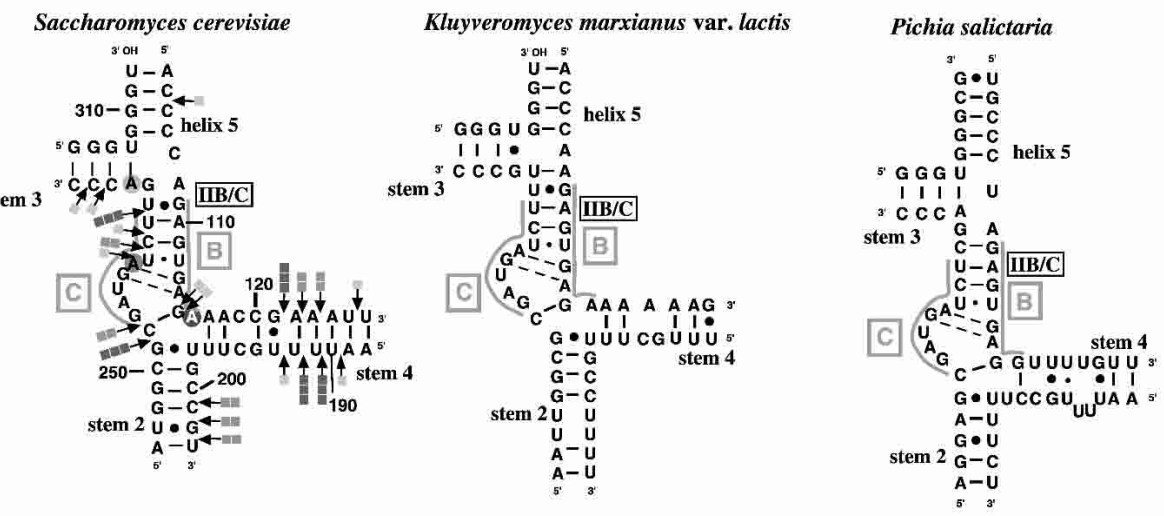

D
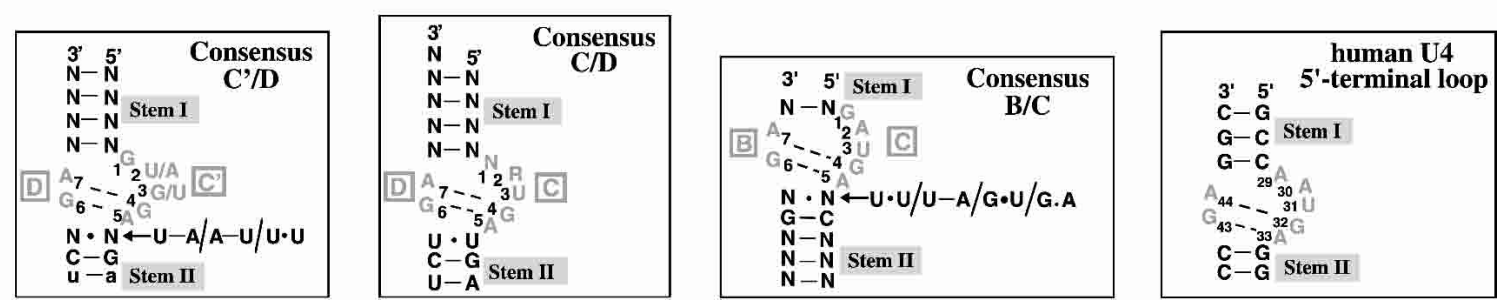

FIGURE 3. (Legend on next page) 
pair, which was formed in the authentic phenol-extracted RNA based on V1 RNase digestion (Mereau et al. 1997; Fig. 3C), was not formed in the transcript (Fig. 2B).

\section{Phylogenetic evolution of the $C^{\prime} / D$ and $B / C$ motifs of U3 snoRNA}

The K-turn structures of U3 snoRNA, that were shown above to be formed or recognized by the Snu13/15.5 kD protein, have peculiar features. In the human $\mathrm{C}^{\prime} / \mathrm{D} \mathrm{K}$-turn, the $\mathrm{U}$ residue at position 3, that is expected to interact directly with the protein, is replaced by a $\mathrm{G}$ residue (Fig. $1 \mathrm{C}$ ), and in the S. cerevisiae $\mathrm{C}^{\prime} / \mathrm{D} \mathrm{K}$-turn, the residue $5^{\prime}$ to the protruding $\mathrm{U}$ residue (residue 2 in the internal loop) is a $U$ residue instead of a purine residue (Fig. 2C). In addition, the $\mathrm{B} / \mathrm{C}$ K-turns of both human and $\mathrm{S}$. cerevisiae U3 snoRNAs have a very short helix Ів/C (one canonical pair and one wooble pair in the human RNA, and one canonical pair in the S. cerevisiae RNA). To test whether the presence of peculiarities in each of the two K-turns was evolutionary conserved, we compared all U3 snoRNAs whose nucleotide sequences were available in GenBank. They include RNAs from three vertebrates (Homo sapiens, Mus musculus, and Xenopus laevis), two higher plants (tomato Lycopersicon esculentum and wheat Triticum aestivum), unicellular algaea (Chlamydomonas reinhardtii and Euglena gracilis), three protozoan (Crithidia fasciculata, Trypanosoma brucei, and Tetrahymena thermophila), one budding yeast (Schyzosaccharomyces pombe) and six fission yeasts (Saccharomyces cerevisiae, Hansenula wingei, Kluyveromyces bulgaricus, Kluyveromyces delphensis, Kluyveromyces marxianus var. fragilis, Kluyveromyces marxianus var. lactis). In addition, using PCR amplification from genomic DNA, followed by sequence analysis, we sequenced the U3 snoRNAs from four yeast species of the Pichia genus (Pichia anomala, Pichia guilliermondii, Pichia pastoris, and Pichia salictaria). The fact that the sequenced Pichia genes were bona fide genes was verified by direct sequence analysis of the U3 snoRNAs extracted from these Pichia strains.
As shown in Figure 3A, base-compensatory mutations in stem IC'/D preserve the possibility of forming K-turn motifs in the $\mathrm{C}^{\prime} / \mathrm{D}$ boxes of all studied U3 snoRNAs. Interestingly, in the $\mathrm{C}^{\prime} / \mathrm{D}$ motifs of the three vertebrates examined, the residue expected to be located in the binding pocket is a $\mathrm{G}$. This seems to be a specific property of vertebrates, because in all the other species, except $P$. guilliermondii and $C$. reinhardtii ( $C$ residue), a canonical $U$ residue is found at this position. Furthermore, in all the fission yeasts and in higher plants, residue number 2 in the loop is a $U$ residue instead of a purine residue (Fig. $3 A, D)$. Note that this is not the case in U3 snoRNA from the budding yeast $S$. pombe. Based on the 21 structures compared, we established a consensus motif for the $\mathrm{C}^{\prime} / \mathrm{D}$ box pair (Fig. 3D). Sequence constraints are observed in stem II, the two sheared pairs are followed in succession by: a U.U, U-A, or a A-U pair, a conserved G-C pair (only two exceptions: G.U in E. gracilis and U.C in T. thermophila), and a pair of noncomplementary residues (AG, CU, AC) or more frequently an A-U pair. In contrast, the sequence of stem $\mathrm{I}$ is variable. The consensus motif established for the C'/D box pair shows one remarkable difference compared to the consensus motif established for the C/D box pair of guide RNAs (Watkins et al. 2000): Instead of being occupied by a variable residue, position 1 in the internal loop is always occupied by a $\mathrm{G}$ residue (Fig. 3D).

Comparative analysis of the B/C K-turn motif (Fig. 3B) shows that, although some base-compensatory mutations preserve the possibility of forming helix IIв/C, this stem is subjected to sequence contrainsts, the two sheared pairs are followed in succession by: a highly conserved U.U pair (a few exceptions are A-U in X. laevis and C. reinhardtii, A.G in C. fasciculata and T. brucei, $\mathrm{U} \cdot \mathrm{G}$ in T. thermophila), a highly conserved $\mathrm{C}-\mathrm{G}$ pair (only three exceptions: C.C in C. fasciculata, C. reinhardtii, and T. brucei), an U-A (yeasts), A-U (T. thermophila), or G-C (all the other species from vertebrates, plants, and protozoan) pair. In contrast to the $\mathrm{C}^{\prime} / \mathrm{D}$ motif, the tetranucleotide in the internal loop of the $\mathrm{B} / \mathrm{C}$ motif is always a canonical

FIGURE 3. Phylogenic analysis of the K-turn structures formed by the $\mathrm{C}^{\prime} / \mathrm{D}$ and $\mathrm{B} / \mathrm{C}$ boxes of U3 snoRNA. The sequence from human (Homo sapiens), the mouse (Mus musculus), Xenopus laevis, tomato (Lycopersicon esculentum), wheat (Triticum aestivum), Chlamydomonas reinhardtii, Euglena gracilis, Crithidia fasciculata, Tetrahymena thermophila, Schyzosaccharomyces pombe, Saccharomyces cerevisiae, Hansenula wingei, Kluyveromyces bulgaricus, Kluyveromyces delphensis, Kluyveromyces marxianus var. fragilis, and Kluyveromyces marxianus var. lactis, are numbered AF020531, X04258, Z12613, X14411, X63065, AJ001179, AF277396, X71349, U27297, X56982, X91037, X91005, Y14752, Z78432, Y14751, X87402 in GenBank: http://www.ncbi.nlm.nih.gov/. The sequence from Trypanosoma brucei U3 snoRNA was taken from Hartshorne and Toyofuku (1999). The sequence from Pichia anomala strain CBS 247, Pichia guilliermondii strain CBS 2030, Pichia pastoris strain CBS 704, and Pichia salictaria strain CBS 5456 are from this study (AJ507111, AJ507112, AJ507113, AJ507109, respectively numbered in GenBank). The K-turn structures, which can be formed by the $\mathrm{C}^{\prime} / \mathrm{D}$ motif of all the compared U3 snoRNAs, are shown in $(A)$. These structures were divided into three blocks, according to the sequence of their internal loop. The K-turn structures, which can be formed by B/C motifs of all compared U3 snoRNAs, are shown in $(B)$. In $(C)$, the structures that can be formed at the junction between helices $5,4,2$, and 3 in the $S$. cerevisiae, K. marxianus var. lactis, and P. salictaria U3 snoRNAs are compared. Numbering of helices 2, 3, 4, and 5 is done according to Segault et al. (1992). Nucleotide numbering in the S. cerevisiae U3 snoRNA, as well as the B and C boxes, and the helix IIB/C are indicated. The yields and positions of V1 RNase cleavages previously found in U3 snoRNA phenol-extracted from the S. cerevisiae U3 snoRNP (Mereau et al. 1997) are also represented on the S. cerevisiae U3 snoRNA structure (arrows associated with one gray square, two darker gray squares, or three very dark squares correspond to low, medium, or strong cleavage, respectively). In $(D)$, the consensus motifs established for the $\mathrm{C}^{\prime} / \mathrm{D}$ and B/C motifs of the U3 snoRNAs compared in this study are shown, as well as the consensus motif established for the C/D motif of guide snoRNAs (Watkins et al. 2000) and the K-turn structure recognized by the $15.5-\mathrm{kD}$ protein in human U4 snRNA (Nottrott et al. 1999). 
one (AUGA, except for wheat). As for the $\mathrm{C}^{\prime} / \mathrm{D}$ motif, residue at position 1 in the internal loop is always a G residue (except for Kluyveromyces marxianus var. fragilis and Pichia guilliermondii, where an $\mathrm{A}$ and a $\mathrm{C}$ residue are found, respectively). In all the species studied, stem Ів/C is either not present or reduced to one or two base pairs. In agreement with observations of Granneman et al. (2002), the consensus motif established for the B/C motif (Fig. 3D) differs from that established for the $\mathrm{C} / \mathrm{D}$ and $\mathrm{C}^{\prime} / \mathrm{D}$ motifs by the presence of a $\mathrm{C}-\mathrm{G}$ pair, instead of a $\mathrm{G}-\mathrm{C}$ pair in stem II.

Based on previous and present RNA structure probing, we propose a secondary structure model for the region of $S$. cerevisiae $\mathrm{U} 3$ snoRNA containing the $\mathrm{B} / \mathrm{C}$ motif. Figure $3 \mathrm{C}$ shows that base-compensatory mutations in helices 2,3 , and IIв/C preserve the possibility of forming this structure in Kluyveromyces and Pichia species.

\section{Snu13p binds the U3 snoRNA $C^{\prime} / D$ and $B / C$ box pairs independently}

Having shown that the $\mathrm{C}^{\prime} / \mathrm{D}$ and $\mathrm{B} / \mathrm{C}$ boxes of $\mathrm{U} 3$ snoRNA are characterized by sequence deviation in the asymmetric internal loop and a highly reduced stem I, respectively, it was important to evaluate the relative affinity of these motifs for the $15.5-\mathrm{kD} /$ Snu13 protein. In addition, the presence of two $15.5-\mathrm{kD} / \mathrm{Snu} 13$ protein binding sites in U3 snoRNA opened the possibility of a cooperative binding to these two sites. To obtain information on these two points, we mutated either box D (transcript yU3A $\Delta 2,3,4$ mutD) or box B (transcript yU3A $\Delta 2,3,4 \mathrm{mutB}$ ) in the yU3A $\Delta 2,3,4 \mathrm{RNA}$. The mutations were designed to abolish one of the two K-turn structures (Fig. 4A). The ability of the WT and variant RNAs to form complexes with Snu13p was tested by gelshift experiments (Fig. 4B). Two distinct complexes, RNP1 and RNP2, were formed with the WT RNA. RNP1 and RNP2 were formed at protein concentrations inferior to 125 $\mathrm{nM}$ ([RNA]/[protein] ratio inferior to $1 / 400)$, and comprised between 250 and $500 \mathrm{nM}$ ([RNA]/[protein] ratio between $1 / 750$ and 1/1500), respectively. On the basis of their electrophoretic mobilities (Fig. 4B), RNP1 and 2 probably contained one and two Snu13p molecules, respectively. Only one type of RNP was formed with each of the variant RNAs (Fig. 4B). For RNA mutD, the required protein concentration (between 50 and $75 \mathrm{nM}$ ), was similar to that required for RNP1 formation with the WT RNA. A higher protein concentration was needed to get an RNP with the mutB RNA (between 250 and $500 \mathrm{nM}$ ). It was similar to that necessary to convert RNP1 formed with WT RNA into RNP2. This suggested an independent binding of Snu13p to each of the $B / C$ and $C^{\prime} / D$ motifs, with a three- to sevenfold higher affinity for the $\mathrm{B} / \mathrm{C}$ motif compared to the $\mathrm{C}^{\prime} / \mathrm{D}$ motif. This hypothesis was confirmed by comparison of the affinity of Snu13p for two small RNAs, yU3C'/D and yU3B/C, containing the $\mathrm{C}^{\prime} / \mathrm{D}$ and $\mathrm{B} / \mathrm{C}$ motifs, respectively. In RNA

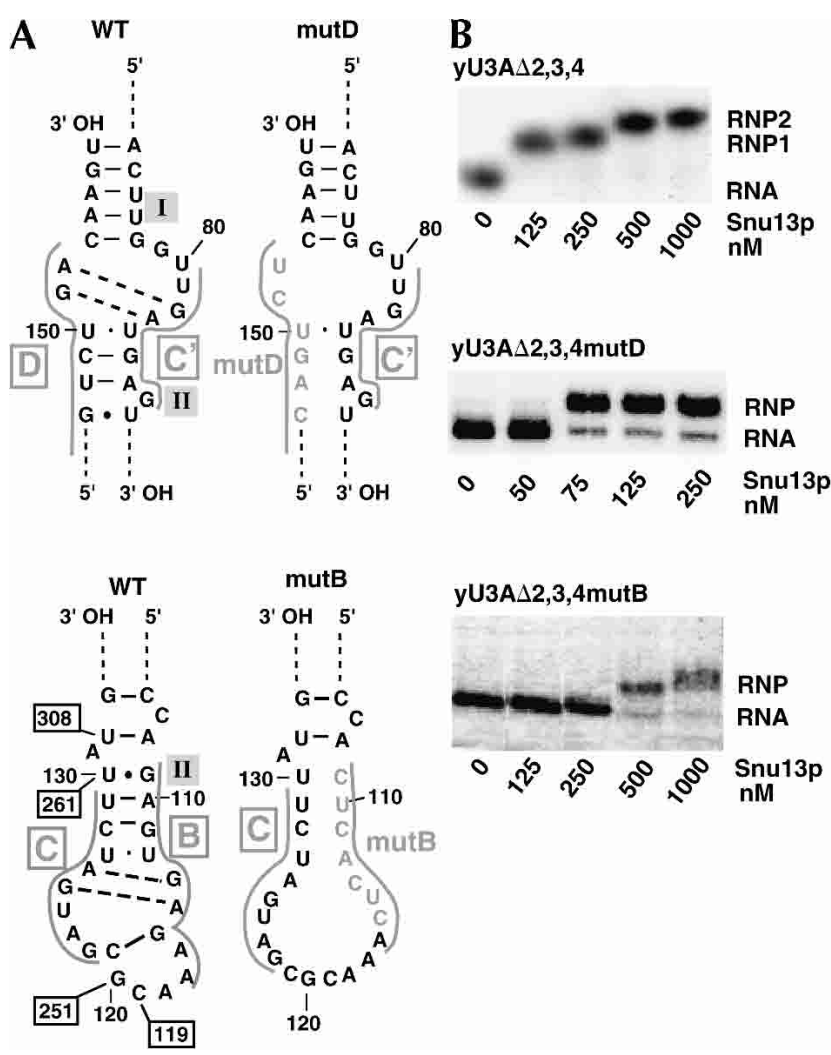

FIGURE 4. Snu13p binds the $\mathrm{C}^{\prime} / \mathrm{D}$ and $\mathrm{B} / \mathrm{C}$ motifs of U3 snoRNA independently. The base substitutions performed in the mutD and mutB variant yU3A $\Delta 2,3,4$ RNAs are shown in $(A)$ (base substitutions are shown in gray characters). In (B), RNP complexes were formed by incubation of 5 fmoles of uniformly labeled WT or yU3A $\Delta 2,3,4$ mutB RNA in the presence of Snu13p at a 125, 250, 500, or $1000 \mathrm{nM}$ concentration or of 5 fmoles of yU3A $\Delta 2,3,4$ mutD RNA in the presence of Snu13p at a 50,75, 125, or $250 \mathrm{nM}$ concentration. All complexes were formed in the presence of $10 \mu \mathrm{g}$ of yeast tRNAs in the conditions described in Materials and Methods. Lanes (0) are control experiments in the absence of protein. Complexes were fractionated by electrophoresis in a nondenaturing $6 \%$ polyacrylamide gel. The positions of the RNA-protein complexes (RNP1 and RNP2 for yU3A $\Delta 2,3,4$ WT RNA and RNP for yU3A $\Delta 2,3,4$ mutD and yU3A $\Delta 2,3,4$ mutB RNAs) and of the free RNA (RNA) are indicated on the right of the autoradiograms.

$\mathrm{yU} 3 \mathrm{C}^{\prime} / \mathrm{D}$, the yeast U3 snoRNA segments 74 to 86 and 324 to 333 were joined together by a tetraloop (Fig. $5 \mathrm{~A}$ ). The $\mathrm{yU} 3 \mathrm{~B} / \mathrm{C}$ RNA contained the terminal stem-loop structure of RNA yU3A $\Delta 2,3,4$ (position 101 to 138) (Fig. 5C). As above, gel-shift experiments were performed with uniformly labeled $\mathrm{yU} 3 \mathrm{C}^{\prime} / \mathrm{D}$ and $\mathrm{yU} 3 \mathrm{~B} / \mathrm{C}$ RNAs and recombinant Snu13p at increasing concentrations (from 50 to $1500 \mathrm{nM}$ ). As illustrated in Figure 5B and D, Snu13p had a higher affinity for the yU3B/C RNA (RNA was totally shifted at a $250 \mathrm{nM}$ Snu13p concentration) compared to the $y \mathrm{U}_{3} \mathrm{C}^{\prime} / \mathrm{D}$ RNA (RNA was not totally shifted, even at a Snu13p concentration of $1500 \mathrm{nM}$ ). These data, that were reproducibly obtained in different experiments, were surprising because secondary structure analysis (not shown) revealed that the $\mathrm{B} / \mathrm{C}$ helix-loop-helix structure is not preformed in the na- 


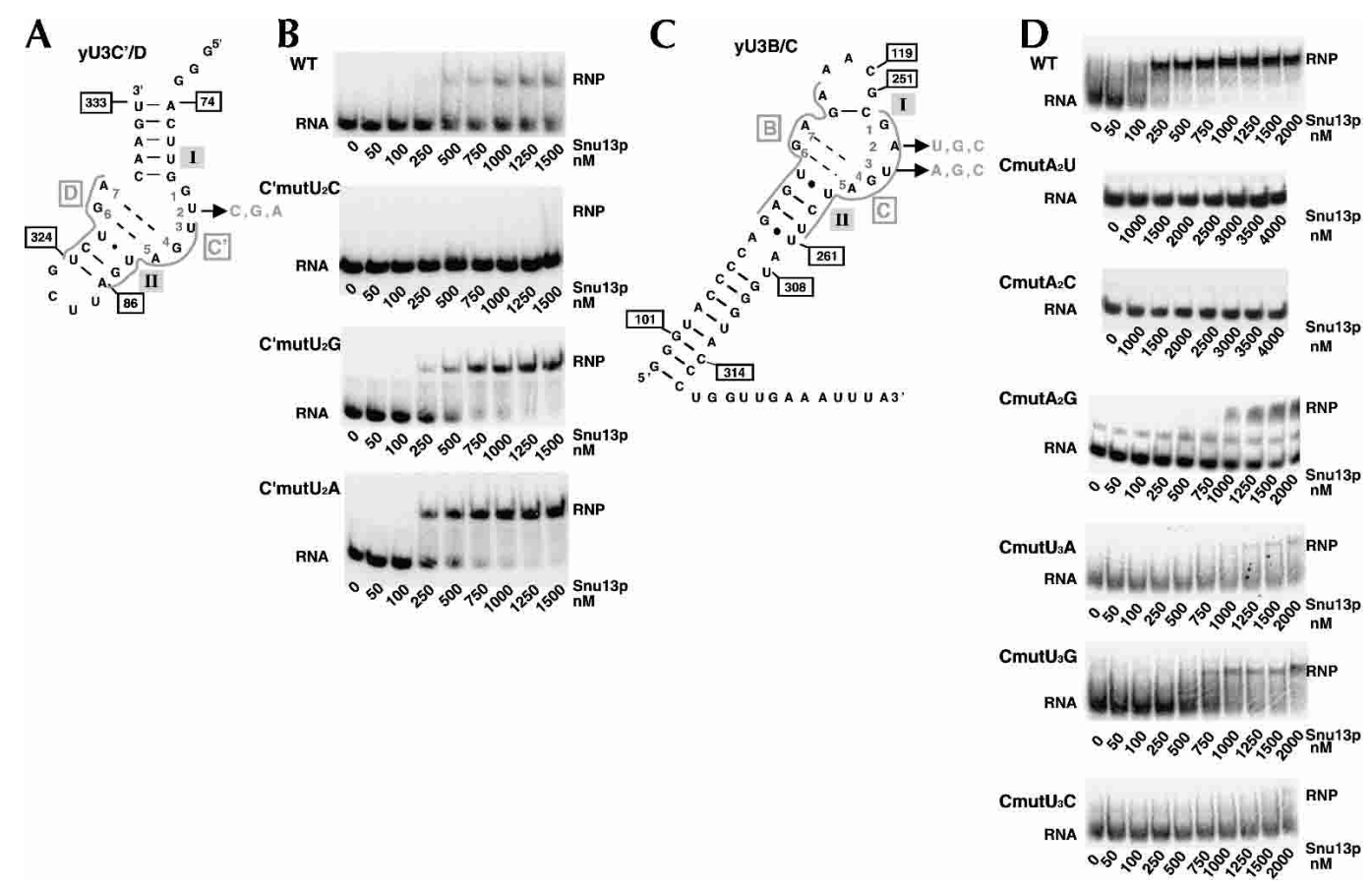

FIGURE 5. Effects of point mutations in $\mathrm{yU} \mathrm{C}^{\prime} / \mathrm{D}$ and $\mathrm{yU} 3 \mathrm{~B} / \mathrm{C}$ RNAs on Snu13p binding. The proposed secondary structure of the $\mathrm{yU} 3 \mathrm{C}^{\prime} / \mathrm{D}$ RNA containing the $\mathrm{C}^{\prime} / \mathrm{D}$ motif of yeast U3 snoRNA is shown in $(A)$. Positions in yeast U3 snoRNA of the extremities of the two yeast U3 snoRNA segments present in $\mathrm{yU} 3 \mathrm{C}^{\prime} / \mathrm{D}$ RNA are indicated in black squares. The base substitutions that were generated at position 2 of the internal loop are indicated. (B) Autoradiograms of gel-shift assays performed with 5 fmoles of uniformely labeled WT and variant yU3C'/D RNAs and the recombinant Snu13 protein at various concentrations indicated below the lanes. $(C)$ The proposed secondary structure of the yU3B/C RNA containing the B/C motif of U3 snoRNA. Positions in yeast U3 snoRNA of the extremities of the three yeast U3 snoRNA segments present in $\mathrm{yU} 3 \mathrm{~B} / \mathrm{C}$ RNA are indicated in black rectangles. The base substitutions that were generated at positions 2 and 3 of the internal loop are indicated. (D) Autoradiograms of gel-shift assays performed with 5 fmoles of uniformly labeled WT and variant yU3B/C RNAs and the recombinant Snu13 protein at various concentrations indicated below the lanes.

ked $\mathrm{yU} 3 \mathrm{~B} / \mathrm{C}$ RNA, and because stem IB/C is reduced to one base pair.

\section{Strong effects of Pu2Py and U3CorA substitutions in the asymmetric loops of U3 snoRNA K-turns}

One possible explanation for the low affinity of Snu13p for the S. cerevisiae $\mathrm{C}^{\prime} / \mathrm{D}$ motif could be the presence of a $\mathrm{U}$ residue at position 2 in the internal loop instead of a purine. To test this hypothesis, $\mathrm{U}$ at position 2 was replaced by all other possible nucleotides: C (variant $\mathrm{C}^{\prime}$ mutU2C), G (variant $\mathrm{C}^{\prime}$ mutU2G), and $\mathrm{A}$ (variant $\mathrm{C}^{\prime}$ mutU2A). As shown by gel-shift experiments (Fig. 5B), replacement by a $\mathrm{C}$ residue completely abolished Snu13p binding. The U2G and the U2A substitutions increased the RNA binding capacity, because a complete shift was obtained at Snu13p concentrations of $750 \mathrm{nM}$. Nevertheless, the affinities observed for these two $\mathrm{yU} 3 \mathrm{C}^{\prime} / \mathrm{D}$ variants remained lower than that observed for the WT yU3B/C RNA (total shift for a concentration comprised between 250 and $500 \mathrm{nM}$; Fig. 5D). It was also interesting to test the effect of base substitutions at position 2 in the $\mathrm{B} / \mathrm{C}$ motif. As illustrated in Figure 5D, substitutions by a pyrimidine residue (variant CmutA2U and CmutA2C) completely abolished Snu13p binding. Sub- stitution by a $\mathrm{G}$ residue also had a strong negative effect: a complex was detected at Snu13p concentration in the $\mu \mathrm{M}$ range. Hence, the A residue present at position 2 in the WT $\mathrm{B} / \mathrm{C}$ motif is the optimal residue for Snu13p binding. As these data showed that substitution at position 2 in the $\mathrm{B} / \mathrm{C}$ motif had very strong effects on protein binding, we also tested the effects of base substitution at position 3. As shown in Figure 5D, no complex was formed after U3C substitution (variant CmutU3C), a trace of complex was formed at a high Snu13p concentration for the U3A substitution (variant CmutU3A). The highest affinity was found for the U3G substitution (variant CmutU3G). However, a $1 \mu \mathrm{M}$ Snu13p concentration was required to obtain a total shift of the RNA. Hence, mutations at positions 2 and 3 in the $\mathrm{B} / \mathrm{C}$ motif had a stronger deleterious effect on Snu13p binding than the similar mutations in the $C^{\prime} / D$ motif.

\section{Importance of the identity of residues at positions $\mathbf{2}$ and 3 of the B/C motif for U3 snoRNA functionality}

As we showed strong effects on Snu13p affinity of the identity of residues at positions 2 and 3 in the $\mathrm{B} / \mathrm{C} \mathrm{K}$-turn, and at position 2 in the $\mathrm{C}^{\prime} / \mathrm{D} \mathrm{K}$-turn, it was of interest to test for 
A

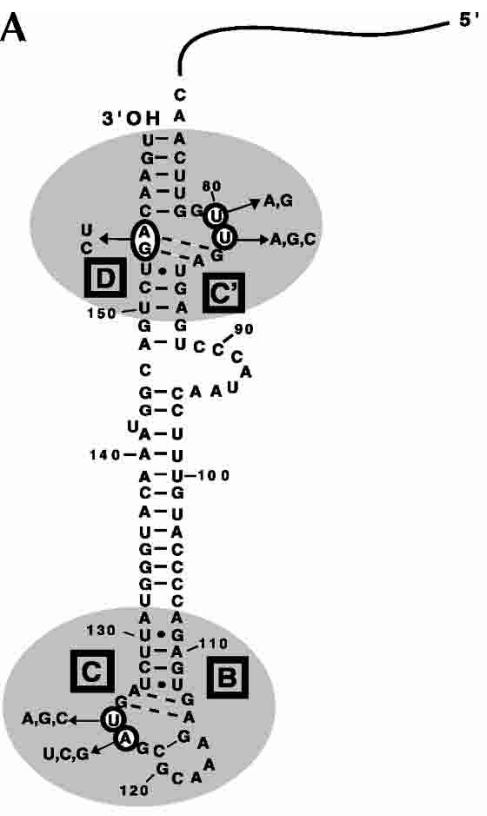

C $\quad 20^{\circ} \mathrm{C}$
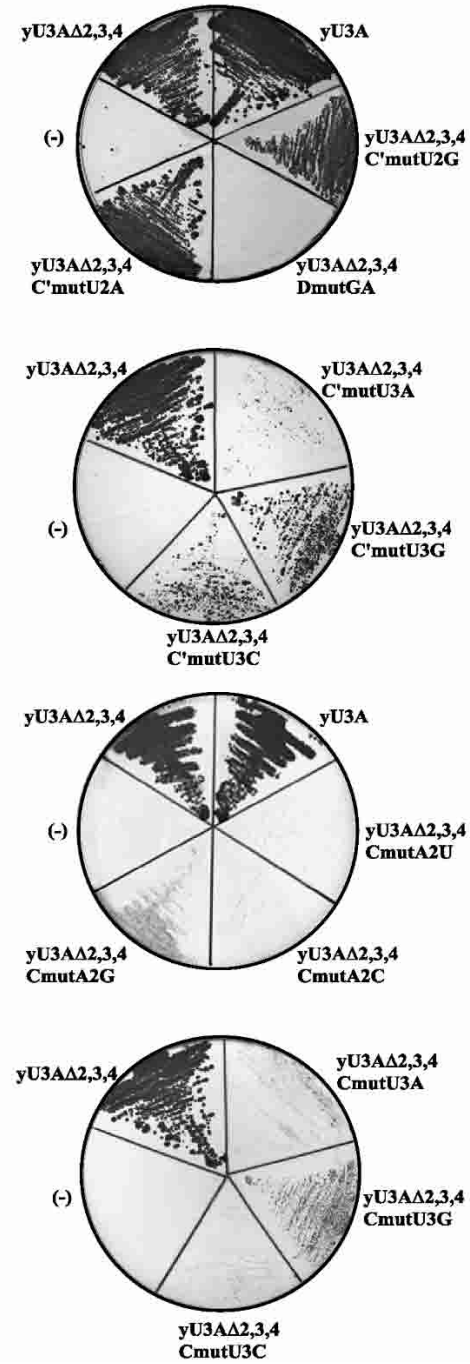

B

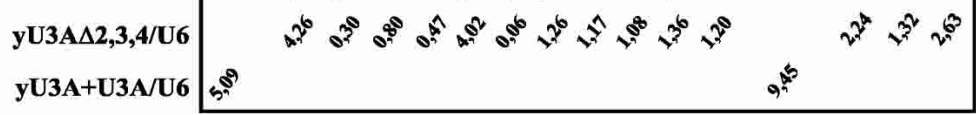

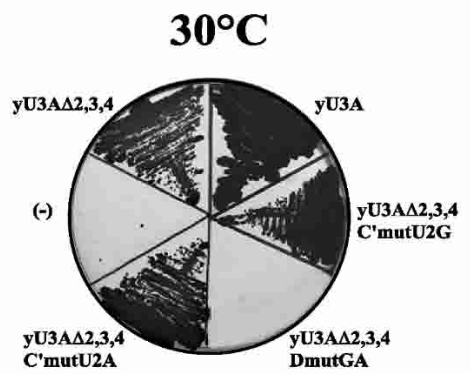
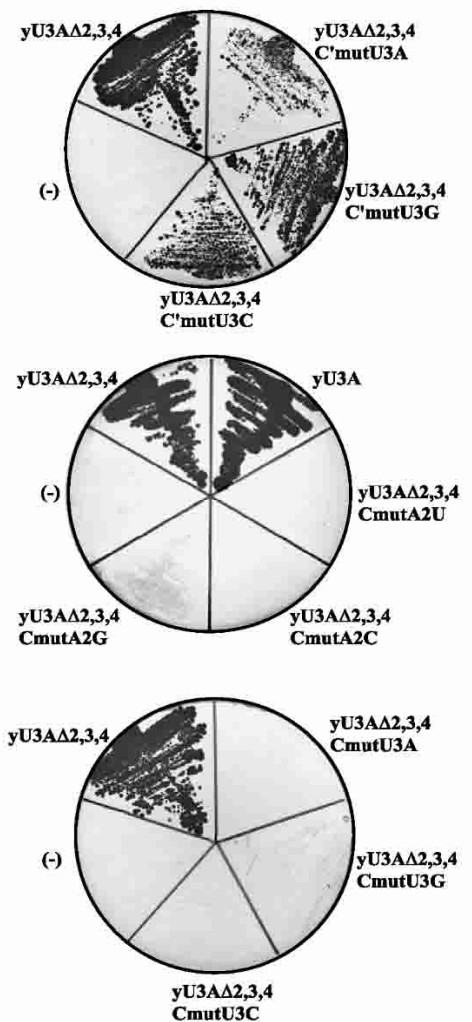

$37^{\circ} \mathrm{C}$
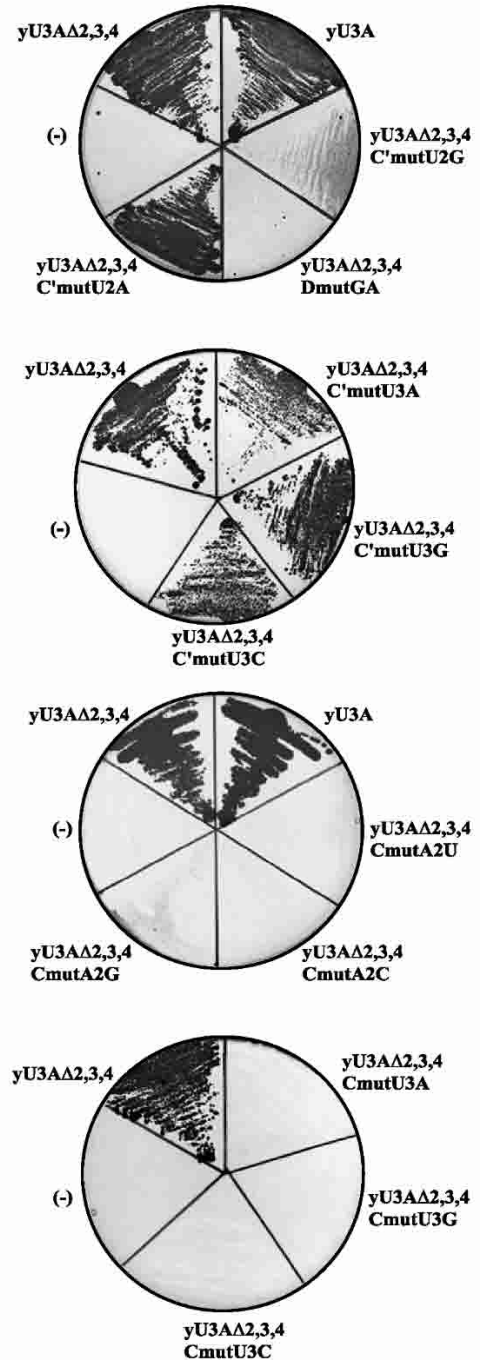

FIGURE 6. (Legend on next page) 
the effect of these base substitutions on yeast U3 snoRNA functionality. Tests were made in the S. cerevisiae JH84 strain, which was transformed with recombinant pASZ11 plasmids containing WT or variant yU3A $\Delta 2,3,4$ RNA coding sequences (Fig. 6A). In these plasmids, the yU3A $\Delta 2,3,4$ genes were placed under the control of the natural U3A gene transcriptional promoter. Growth was tested both on galactose (expression of the U3A chromosomal gene) and on glucose (no expression of the U3A chromosomal gene; Hughes and Ares 1991) and for each variant, the experiment was repeated three times to control the reproducibility of the data. As mentioned above, only a very limited reduction of the growth kinetics was detected for the yU3A $\Delta 2,3,4$ gene, compared to the WT U3A gene, and Northern blot analysis demonstrated the stability of the truncated U3 snoRNA (Fig. 6B). In contrast, in agreement with previous data (Samarsky and Fournier 1998), substitution of the GA dinucleotide (positions 153-154) in box D, which abolishes the possibility to form the $\mathrm{C}^{\prime} / \mathrm{D} \mathrm{K}$-turn structure, did not allow JH84 growth on galactose at any of the tested temperatures, and the yU3A $\Delta 2,3,4-\mathrm{DmutGA}$ variant RNA was not stable (Fig. 6B). This confirmed the necessity to form a K-turn structure with the $\mathrm{C}^{\prime} / \mathrm{D}$ motif for both U3 RNA stability and snoRNP assembly. As expected, conversion of the $\mathrm{U}$ residue at position 2 in the $\mathrm{C}^{\prime} / \mathrm{D}$ internal loop into a canonical purine residue (variant $\mathrm{C}^{\prime}$ mutU2A), which increased Snu13p affinity for the C'/D motif (Fig. 5B), had no detectable effect on both RNA stability (Fig. 6B) and growth (Fig. 6C). Surprisingly, the U2G substitution, which was also found to increase Snu13p affinity (Fig. 5B), led to a thermosensitive phenotype. Growth was markedly affected at $37^{\circ} \mathrm{C}$ (Fig. $6 \mathrm{C}$ ). Base substitutions at position 3 of the $\mathrm{C}^{\prime} / \mathrm{D}$ motif had strong negative effects on RNA stability and led to cryosensitive phenotypes (Fig. 6C). Apart from U residue, found in the WT RNA, G residue is the more favorable residue at this position (Fig. 6C). Interestingly, whereas the U3G substitution decreased the yU3A $\Delta 2,3,4$ RNA stability by a factor of about 6 at $30^{\circ} \mathrm{C}$, the growth defect at this temperature was not strong. The U3C substitution had only a slightly greater negative effect than the U3G substitution. The effect of the U3A substitution was more dramatic, especially at $20^{\circ} \mathrm{C}$ (Fig. $6 \mathrm{C}$ ). The stability of this variant RNA was also very low at $30^{\circ} \mathrm{C}$ (Fig. $6 \mathrm{~B}$ ). Hence, in accord with previous data (Samarsky and Fournier 1998), defects in both stability and functionality were found for mutations in the $\mathrm{C}^{\prime}$ box.

Substitutions at positions 2 and 3 in the internal loop of the $\mathrm{B} / \mathrm{C}$ motif had more limited effects on RNA stability (Fig. 6B), but greater effects on yU3A $\Delta 2,3,4$ RNA functionality (Fig. 6C). Indeed, yU3A $\Delta 2,3,4$ RNAs with A2C or A2U substitution in the $\mathrm{B} / \mathrm{C}$ motif were not able to ensure growth at any of the tested temperatures, and only a very slow growth was observed for the A2G substitution. Hence, to attain normal growth, an $\mathrm{A}$ residue is required at position 2 of the B/C K-turn. Furthermore, yU3A $\Delta 2,3,4$ RNAs with $\mathrm{U} 3 \mathrm{~A}, \mathrm{U} 3 \mathrm{G}$, or $\mathrm{U} 3 \mathrm{C}$ substitutions in the $\mathrm{B} / \mathrm{C}$ motif did not ensure growth at $30^{\circ} \mathrm{C}$ and $37^{\circ} \mathrm{C}$, and only a very slow growth was detected at $20^{\circ} \mathrm{C}$. At this temperature, variant U3G ensured growth at a slightly higher efficiency compared to the two other variants (Fig. 6C). Hence, base substitutions at both positions 2 and 3 in the $\mathrm{B} / \mathrm{C}$ motif had drastic effects on yU3A $\Delta 2,3,4$ RNA functionality. This is in contrast with the mild effects on yU3A $\Delta 2,3,4$ RNA functionality found for base substitutions at positions 2 and 3 in the $\mathrm{C}^{\prime} / \mathrm{D}$ K-turn.

\section{DISCUSSION}

\section{Protein 15.5-kD/Snu13 can bind RNA without preexisting helix-loop-helix structure}

Based on the structure of the $15.5-\mathrm{kD} / \mathrm{U} 4$ snRNA complex (Vidovic et al. 2000), all RNA recognition sites of the 15.5$\mathrm{kD} /$ Snu13 protein were proposed to be able to form a Kturn structure (Watkins et al. 2000). However, the question raised is to know whether the $15.5 \mathrm{kD} / \mathrm{Snu} 13$ protein requires a preexisting helix-loop-helix structure for binding or if it can convert terminal loops into K-turn structures upon binding. We previously found that in naked U4 snRNA, the helix-loop-helix structure corresponding to the $\mathrm{K}$-turn is in equilibrium with a structure containing only helix I and a large terminal loop, and we proposed that the $15.5-\mathrm{kD} / \mathrm{Snu} 13$ protein binds the preformed helix-loop-helix structure and displaces the equilibrium towards this structure (Mougin et al. 2002). Based on the present data, a similar proposal can be made for binding of the Snu13/ $15.5-\mathrm{kD}$ protein to the $\mathrm{C}^{\prime} / \mathrm{D}$ motif (Figs. 1,2). However, this cannot be the case for the $\mathrm{B} / \mathrm{C}$ motif, because the helix-

FIGURE 6. Effects on cell growth of point mutations in the internal loops of the $\mathrm{C}^{\prime} / \mathrm{D}$ and $\mathrm{B} / \mathrm{C}$ motifs of $\mathrm{yU} 3 \mathrm{~A} \Delta 2,3,4 \mathrm{RNA}$. In $(A)$, the point mutations that were generated in the yU3A $\Delta 2,3,4$ RNA are represented on the secondary structure established for this RNA. The relative stabilities of the yU3A $\Delta 2,3,4$ WT and variant RNAs in the JH84 S. cerevisiae strain grown at $30^{\circ} \mathrm{C}$ in YPD medium (see Materials and Methods), were compared to that of the entire U3 snoRNA (yU3A) by Northern blot analysis $(B)$. The $5^{\prime}$-end labeled oligonucleotide RT-yU3 was used as the probe and for an internal control, a simultaneous hybridization was made with a 5 '-end labeled oligonucleotide complementary to U6 snRNA (RT-yU6, see Table 1). The values obtained by dividing the radioactivity measured in the band corresponding to U3 snoRNA or yU3A $\Delta 2,3,4$ RNA by that measured in the band corresponding to U6 snRNA are given below the lanes (U3A/U6 or yU3A $\Delta 2,3,4 / \mathrm{U} 6$ for cells expressing the yU3A $\Delta 2,3,4 \mathrm{WT}$ or variant RNAs, and (yU3A+U3A)/U6 for cells expressing the yU3A RNA). Growth of the S. cerevisiae JH84 strain transformed with plasmid pASZ11 (-), pASZ11::yU3A, WT, or variant pASZ11::yU3A $\Delta 2,3,4$ on YPD plates at $20^{\circ} \mathrm{C}, 30^{\circ} \mathrm{C}$, and $37^{\circ} \mathrm{C}$ is shown in $(C)$. In these experiments, the S. cerevisiae JH84 cells were grown in liquid YPG medium for $48 \mathrm{~h}$, and then $24 \mathrm{~h}$ in liquid YPD medium before spreading on YPD plates. Growth at $30^{\circ} \mathrm{C}$ and $37^{\circ} \mathrm{C}$ was for $48 \mathrm{~h}$, growth at $20^{\circ} \mathrm{C}$ was for $72 \mathrm{~h}$. 
loop-helix structure does not preexist in the naked RNA. As, in addition, Snu13p has a higher affinity for this motif than for the $C^{\prime} / \mathrm{D}$ motif, we conclude that the $15.5-\mathrm{kD} /$ Snu 13 protein does not need a preexisting helix-loop-helix structure for binding. It is probably able to fold RNA into a K-turn upon binding. This does not mean that Snu13p has no RNA structural requirement for binding. In both the human and yeast naked U3 snoRNAs, the part of helix ІІв/C corresponding to canonical pairs is formed, and this may be sufficient for the RNA/protein recognition, which is likely followed by RNA remodeling.

\section{When helix II and the NPuU bulge sequence are present, a single base pair instead of helix I can be sufficient to create a Snu13p binding site}

Our probing of RNA/protein complexes suggests that a stem IB/C with $A-U$ and $G \cdot U$ base pairs is formed upon $15.5-\mathrm{kD}$ protein binding to human U3 snoRNA, whereas a unique $\mathrm{G}-\mathrm{C}$ base pair is formed upon binding of Snu13p to S. cerevisiae U3A snoRNA. Binding of the $15.5-\mathrm{kD} / \mathrm{Snu} 13$ protein to structures with such a highly reduced helix I may seem surprising based on data of a previous analysis of nonconventional $\mathrm{C} / \mathrm{D}$ box snoRNAs (Darzacq and Kiss 2000; Villa et al. 2000). Indeed, processing of C/D snoRNAs, with a very short or absent stem I, was found to require additional base pair interactions present in the $\mathrm{C} / \mathrm{D}$ box snoRNA precursor. Taking into account the present knowledge on the Snu13/15.5-kD protein recognition site, we found that almost all the nonconventional C/D box snoRNAs (hU27, hU31, hU36b, hU37, hU42, hU43, hU44, hU46, hU56, hU76, hU78, mU25, mU27, mU30, mU31, mU36b, mU44, mU78) have two complementary nucleotides that can close the NRUGA (positions 1 to 5 of the K-turn structure) and AG (positions 6 and 7 of the K-turn structure) conserved sequences, and their interaction can allow the formation of a K-turn structure (Fig. 7). In RNA yU3A $\Delta 2,3,4$, formation of the G115-C121 base pair (stem I) in the $\mathrm{B} / \mathrm{C}$ motif, is likely favored by the presence of a short terminal loop joining residues 115 and 121 (Fig. 7). Interestingly, in the nonconventional C/D box snoRNAs, the additional base pair interactions (Darzacq and Kiss 2000), which join the two RNA strands in the snoRNA precursors, generate an internal loop of a size similar to that of the yU3A $\Delta 2,3,4$ terminal loop (Fig. 7). The C. fasciculata and T. brucei U3 snoRNAs (Figs. 3,7) also constitute two natural examples of functional $\mathrm{B} / \mathrm{C}$ motifs, which have a very short helix IB/C (two base pairs) closed by a 5-nt loop.

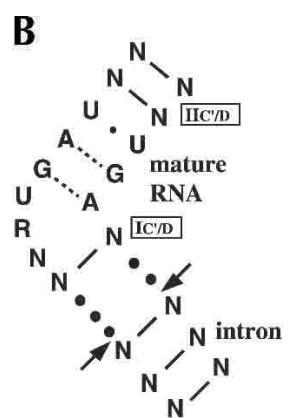

non canonical $\mathrm{C} / \mathrm{D}$ snoRNA C/D motif
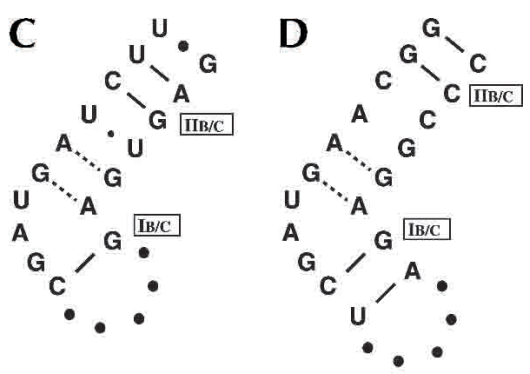

yU3A $\triangle 2,3,4$ B/C motif
Trypanosoma brucei B/C motif
FIGURE 7. The nonconventional C/D box snoRNAs can form K-turn structures with one base pair instead of helix I, as the $y \mathrm{U} 3 \mathrm{~A} \Delta 2,3,4 \mathrm{~B} / \mathrm{C}$ motif. The K-turn structures that can be formed by previfs of conventional $(A)$ and nonconventional $(B)$ C/D box snoRNAs, that were previously studied by Darzacq and Kiss (2000) are compared to the K-turn structures formed by the $\mathrm{yU} 3 \mathrm{~A} \Delta 2,3,4 \mathrm{~B} / \mathrm{C}$ motif $(C)$ and $\mathrm{B} / \mathrm{C}$ motif of $T$. brucei $\mathrm{U} 3$ snoRNA $(D)$.

Taken together, these observations suggest, that if stem II is present as well as all the required residues in the bulged sequence, one pair of complementary bases, instead of stem $\mathrm{I}$, is likely necessary and sufficient to create a $15.5-\mathrm{kD} /$ Snu13p binding site.

\section{Formation of the G115-C252 base pair explains previous data on authentic yeast U3 snoRNA}

In the conditions used for probing the yU3A RNA in this study (Fig. 2D,E) (low $\mathrm{MgCl}_{2}$ concentration $2.5 \mathrm{mM}$ ), residue C252 was accessible to DMS. Hence, the G-C pair (115-252) was not formed in all yU3A molecules. In contrast, in previous analysis of the authentic S. cerevisiae U3 snoRNA, that were performed at a higher $\mathrm{MgCl}_{2}$ concentration $\left(10 \mathrm{mM} \mathrm{MgCl}_{2}\right)$ on U3 snoRNA which was phenolextracted from U3 snoRNPs (Mereau et al. 1997) (Fig. 3C), formation of the G115-C252 was detected by V1 RNase cleavages (this enzyme cleaves specifically double-stranded or stacked residues). The present proposal of a G115-C252 base pair, that can be stabilized by stacking on stem II, furnishes an explanation for these previous results, that up to now have been considered as puzzling. Differences between present results on an in vitro transcript and previous results on the authentic RNA may have two possible explanations: (1) formation of the G115-C252 base pair is likely favored at a high $\mathrm{Mg}^{2+}$ concentration, and (2) the structure found in the phenol-extracted authentic U3 snoRNA may be the one that was imposed upon Snu13p binding (Fig. 3C). Despite this difference between the authentic U3 snoRNA and the transcript, the validity of the present data is supported by the similarity of RNA protections previously found in the U3 snoRNP (Mereau et al. 1997) with those found in the Snu13p/yU3A $\Delta 2,3,4$ RNA complex (Fig. 2C). Interesting also, the increase of reactivity found for residue A116 in the RNP (Mereau et al. 1997) was also found here in the $y U 3 A \Delta 2,3,4 /$ Snu13p complex (Fig. 2C). 


\section{The presence of a highly reduced stem I in the $B / C$ motif probably generates sequence constraints}

We showed that Snu13p binds both the $\mathrm{C}^{\prime} / \mathrm{D}$ and B/C motifs with a higher affinity for the $\mathrm{B} / \mathrm{C}$ motif than for the $\mathrm{C}^{\prime} / \mathrm{D}$ motif (Fig. 4). Even the U to A substitution at position 2 in the $C^{\prime} / D$ motif, which converted its bulged sequence into a canonical sequence, was not sufficient to enable the $C^{\prime} / D$ motif to attain a Snu13p affinity similar to that for the $\mathrm{B} / \mathrm{C}$ motif. This suggested that the $\mathrm{B} / \mathrm{C}$ sequence and conformation were selected during evolution to optimize Snu13p binding. Indeed, any of the mutations performed in the bulged sequence of the $\mathrm{B} / \mathrm{C}$ motif had dramatic effects on Snu13p binding. For instance, whereas yU3C'/D RNA with a $U$ at the same position binds Snu13p at a high protein concentration, $\mathrm{yU} 3 \mathrm{~B} / \mathrm{C}$ RNA with a $\mathrm{U}$ at position 2 did not, even at a very high protein concentration (Fig. 5D). Even a purine to purine (A to $G$ ) substitution at this position in $y U 3 B / C$ RNA, was highly deleterious for Snu13p binding (Fig. 5D). In addition, whereas hU3 RNA with a G at position 3 in the $\mathrm{C}^{\prime} / \mathrm{D}$ motif binds the $15.5-\mathrm{kD}$ protein (Fig. 1), the $y \mathrm{U} 3 \mathrm{~B} / \mathrm{C}$ RNA with a $\mathrm{G}$ at this position forms a complex with Snu13p only at concentrations in the $\mu \mathrm{M}$ range, and $\mathrm{U}$ to $\mathrm{A}$ and $\mathrm{U}$ to $\mathrm{C}$ substitutions at this position had even greater effects (Fig. 5D). Altogether, this strongly suggested that Snu13p can efficiently recognize the B/C motif with only one base pair instead of helix I, provided that the sequence of the internal loop is optimized. These experimental observations of sequence constraints on the bulge loop of the $\mathrm{B} / \mathrm{C}$ motif are in perfect agreement with the results of our phylogenetic analysis. Indeed, whereas the identities of residues at positions 2 and 3 in the internal loop of the $C^{\prime} / \mathrm{D}$ motif are variable (Fig. 3A,D), the sequence of the internal loop of the $\mathrm{B} / \mathrm{C}$ motif is almost universally conserved (Fig. 3B,D).

\section{Mutations at positions 2 and 3 in the $B / C$ motif of yU3A $\Delta 2,3,4$ RNA affect growth more strongly than the corresponding mutations in the $C^{\prime} / D$ motif}

Data of our in vivo mutational analysis of yU $3 A \Delta 2,3,4$ RNA are also in perfect agreement with results of our phylogenetic analysis. Indeed, according to the observation of a $\mathrm{G}$ residue at position 3 in the $C^{\prime} / D$ motif of vertebrate $\mathrm{U} 3$ snoRNAs and a $\mathrm{C}$ residue at this position in $C$. reinhardtii U3 snoRNA, yU3A $\Delta 2,3,4$ RNA with these two base substitutions ensured growth at $30^{\circ} \mathrm{C}$ and $37^{\circ} \mathrm{C}$. For the U3G substitution, growth at $37^{\circ} \mathrm{C}$ was similar to that for WT RNA. Taking into account the fact that the yeast $\mathrm{C}^{\prime} / \mathrm{D}$ motif has, in addition, the handicap of carrying a $U$ residue instead of a purine residue at position 2, we can imagine that a U3G substitution in a $\mathrm{C}^{\prime} / \mathrm{D}$ motif with a $\mathrm{Pu}$ at position 2 does not significantly alter U3 snoRNA functionality, explaining why this mutation was retained in vertebrates. Note that the U3A substitution in the $\mathrm{C}^{\prime} / \mathrm{D}$ motif, which was found to be the more deleterious for growth (Fig. 6), was not found in naturally occurring U3 snoRNAs (Fig. 3). Interestingly also, a $\mathrm{G}$ residue was never found at position 2 in $C^{\prime} / D$ motifs of U3 snoRNAs (Fig. 3), and we found that this mutation has a thermosensitive phenotype (Fig. 6). However, we have no explanation for this phenotype yet, because Snu13p binds this mutant efficiently in vitro (Fig. 5).

The strong effect on the $\mathrm{yU} 3 \mathrm{~A} \Delta 2,3,4$ function of base substitutions at positions 2 and 3 of the $\mathrm{B} / \mathrm{C}$ motif (Fig. 6C) are also in perfect agreement with the conservation of the identity of these two residues in the course of evolution (Fig. 3B). Effects of U3C base substitution in the B/C motif of entire yeast U3 snoRNA was previously tested by Samarsky and Fournier (1998), and in accord with the present data, the authors observed an absence of growth at $30^{\circ} \mathrm{C}$. However, these authors did not observe a marked growth defect upon $\mathrm{A} 2 \mathrm{U}$ mutation in the $\mathrm{B} / \mathrm{C}$ motif. One explanation might be that the phenotypes observed with $y U 3 A \Delta 2,3,4$ RNA instead of entire U3 snoRNA are exacerbated by the presence of the truncation. The additional sequence in yeast U3, although not essential, may contribute somehow to U3 functionality. In particular, as mentioned above, the G115-C252 base pair may be stabilized by stacking on stem II. The deletion of stem II may thus increase the defects generated by base substitutions in the bulge sequence. However, the validity of our experimental approach is strongly supported by the perfect agreement with the phylogenetic data and also by the very good correlation between the efficiency of yU3A $\Delta 2,3,4$ variant RNAs to ensure growth at $30^{\circ} \mathrm{C}$ (Fig. 6C) and the capacities of their $\mathrm{C}^{\prime} / \mathrm{D}$ and $\mathrm{B} / \mathrm{C}$ motifs to bind Snu13p at this temperature (Fig. 5). This correlation demonstrates the importance of Snu13p binding to the $\mathrm{C}^{\prime} / \mathrm{D}$ and $\mathrm{B} / \mathrm{C}$ motifs for the U3 snoRNP function.

\section{The structural differences between the $C^{\prime} / D$ and $B / C$ motifs may be involved in their specific recrutement of U3 snoRNP proteins}

The $\mathrm{C}^{\prime} / \mathrm{D}$ and $\mathrm{B} / \mathrm{C}$ motifs have different functions and are expected to bind different sets of proteins. The $C^{\prime} / \mathrm{D}$ motif is expected to bind Snu13p, Nop1p, Nop56p, and Nop58p (Gautier et al. 1997; Watkins et al. 1998; Wu et al. 1998; Lafontaine and Tollervey 1999, 2000) and is involved in nucleolar localization, cap formation and RNA stability (Terns and Dahlberg 1994; Lange et al. 1998; Samarsky and Fournier 1998; Narayanan et al. 1999; Speckmann et al. 2000). The B/C motif binds Snu13p and Rrp9p (Lubben et al. 1993; Pluk et al. 1998; Lukowiak et al. 2000; Venema et al. 2000; Watkins et al. 2000). In the absence of the $C^{\prime} / D$ motif, it targets U3 snoRNA to the Cajal bodies (Narayanan et al. 1999; Verheggen et al. 2002). Comparison of the RNA protections in the U3 snoRNP (Mereau et al. 1997) with those described here for the $y U 3 A \Delta 2,3,4$ RNA/Snu13p 
complex provides information on the U3 snoRNA regions covered in the presence of other core snoRNP proteins. In the yeast U3 core snoRNP, the $\mathrm{C}^{\prime} / \mathrm{D}$ motif and its surrounding regions are completely buried (Mereau et al. 1997), in contrast, the B/C motif is moderately protected and the protections observed are very similar to those in the Snu13p/yU3A $\Delta 2,3,4$ RNA complex. The strong protection of the $C^{\prime} / D$ motif in the snoRNP compared to the Snu13p/ RNA complex, may be due to the binding of Noplp, Nop56p, and Nop58p. As in the Snu13p/yU3A $\Delta 2,3,4$ RNA complex, stem IC $/ \mathrm{D}$ is not protected, whereas it is protected in the snoRNP. This stem may be involved in Noplp, Nop56p, and Nop58p binding.

The reduced V1 RNase cleavages in stems 2 and 4 in the U3 snoRNP (Mereau et al. 1997) suggest that Rrp9p may contact these two stems. However, our observation that yU3A $\Delta 2,3,4$ RNA is functional and previous similar observations (Samarsky and Fournier 1998) are not in agreement with the idea that these sequences are essential for Rrp9p binding, as recently suggested (Watkins et al. 2002). Our previous and present phylogenetic analyses of U3 snoRNA (Brule et al. 1996; Fournier et al. 1998) show that these sequences are hypervariable. Based on the present data, one possible role of these sequences may be to increase the ability of the $\mathrm{B} / \mathrm{C}$ motif to form a K-turn structure. This may explain the slight growth difference between JH84 strains transformed by a WT or an yU3A $\Delta 2,3,4 \mathrm{U} 3$ gene.

In addition to the highly reduced stem Iв/C, sequence differences in stem II may be involved in discrimination of the $\mathrm{C}^{\prime} / \mathrm{D}$ and $\mathrm{B} / \mathrm{C}$ motifs by $\mathrm{U} 3$ snoRNP proteins. Indeed, a $\mathrm{C}-\mathrm{G}$ pair is found in stem IIB/C, instead of a $\mathrm{G}-\mathrm{C}$ pair in its $\mathrm{C}^{\prime} / \mathrm{D}$ counterpart (Fig. 3). This G-C pair is also found in the $\mathrm{C} / \mathrm{D}$ consensus motif. As well, the $\mathrm{C}-\mathrm{G}$ pair in the $\mathrm{B} / \mathrm{C}$ motif, like the G-C pair in the $\mathrm{C}^{\prime} / \mathrm{D}$ motif, was highly conserved in the course of evolution (Fig. 3). Furthermore, the recent work of Watkins et al. (2002) demonstrated that substitution of the WT G-C in stem II of U14 snoRNA by a $\mathrm{C}-\mathrm{G}$ does not abolish $15.5-\mathrm{kD}$ protein binding, but abolishes Nop1, Nop56, and Nop58 protein binding and also the nucleolar localization of U14 snoRNA. Thus, the differential recruitment of proteins by the $\mathrm{U} 3 \mathrm{C}^{\prime} / \mathrm{D}$ and $\mathrm{B} / \mathrm{C}$ motifs probably depends upon very subtle sequence and structure differences including this $\mathrm{G}-\mathrm{C}$ to $\mathrm{C}-\mathrm{G}$ substitution in stem II.

\section{MATERIALS AND METHODS}

\section{Strains and growth conditions}

Escherichia coli TG1 was used as the host strain for production of recombinant DNA. It was grown at $37^{\circ} \mathrm{C}$, in Luria Broth medium, with $100 \mu \mathrm{g} / \mathrm{mL}$ of ampicillin added when necessary. S. cerevisiae JH84 (Mata snr17a.Gald:URA3 snr17b::LEU2 his3 ade2 can1; Hughes and Ares 1991), generously provided by J. Hughes, was used to test the functionality of mutated yeast U3 snoRNA genes.
Selection of transformants was made on minimal medium (YNB $0.67 \%$, galactose $2 \%$, histidine $20 \mathrm{mg} / \mathrm{L}$ ). Recombinant JH84 cells were grown in YPG medium $(1 \%[\mathrm{w} / \mathrm{v}]$ yeast extract, $2 \%[\mathrm{w} / \mathrm{v}]$ bactopeptone, and $2 \%[\mathrm{w} / \mathrm{v}]$ D-galactose) or YPD medium $(1 \%$ $[\mathrm{w} / \mathrm{v}]$ yeast extract, $2 \%[\mathrm{w} / \mathrm{v}]$ bactopeptone, and $2 \%[\mathrm{w} / \mathrm{v}] \mathrm{D}-$ glucose). The Pichia anomala strain CBS 247, Pichia guilliermondii strain CBS 2030, Pichia pastoris strain CBS 704, and Pichia salictaria strain CBS 5456 were grown in YPD medium.

\section{Preparation of recombinant proteins}

For preparation of the recombinant Snu13 protein, the SNU13 ORF was PCR amplified from S. cerevisiae W303 genomic DNA. The pair of primers used (SNU13-5'/SNU13-3', Table 1), generated DNA fragments with $B a m \mathrm{HI}$ and XhoI restriction sites at the extremities. The amplified DNA fragments were cloned into plasmid pGEX-6P-1 (Pharmacia), a GST fusion expression vector. The recombinant GST-Snu13 protein was purified from E. coli BL21 cells under native conditions, using Glutathione-Sepharose $4 \mathrm{~B}$ as recommended by the manufacturer (Pharmacia). The eluted GSTSnu13 protein was again bound on Glutathione-Sepharose 4B beads, and was cleaved on the beads using $80 \mathrm{U}$ of PreScission protease (Pharmacia) per $\mathrm{mL}$ of Glutathione-Sepharose bead suspension. Cleavage was performed overnight at $4^{\circ} \mathrm{C}$. The cleaved Snu13 protein had five additional amino acid residues at its $\mathrm{N}$ terminus, compared to the authentic protein. It was dialyzed against buffer D (150 mM KCl; $1.5 \mathrm{mM} \mathrm{MgCl}$; 0.2 mM EDTA; 20 $\mathrm{mM}$ HEPES, $\mathrm{pH} 7.9 ; 10 \%$ glycerol) and stored at $-80^{\circ} \mathrm{C}$. The recombinant $15.5-\mathrm{kD}$ protein was prepared as previously described (Nottrott et al. 1999).

\section{Recombinant plasmids used for in vitro transcription and in vivo assays}

Plasmid $\mathrm{pBS}+\mathrm{SP} 6:$ hU3 used for in vitro production of the human U3 snoRNA was provided by R. Lührmann. Phage M13mp9::T7-snR17A (Segault et al. 1992), was used for in vitro transcription of the entire yeast U3A snoRNA, and was the starting material for production by site-directed mutagenesis of phage M13mp19::T7-yU3A $\Delta 2,3,4$. Site-directed mutagenesis was achieved by the method of Kramer et al. (1984) using oligonucleotide yU3A $\Delta 2,3,4$ (Table 1). In RNA yU3A $\Delta 2,3,4$, the three stemloop structures 2, 3, and 4 were eliminated. The box $B$ and $\mathrm{D}$ encoding sequences of phage M13mp19::T7-yU3A $\Delta 2,3,4$ were mutated individually by the method of Kramer et al. (1984) using oligonucleotide $\mathrm{yU} 3 \mathrm{~A} \Delta 2,3,4 \mathrm{mutB}$ or $\mathrm{yU} 3 \mathrm{~A} \Delta 2,3,4 \mathrm{mutD}$, respectively (Table 1) (resulting phages M13mp19::T7$\mathrm{yU} 3 \mathrm{~A} \Delta 2,3,4$ mutB and mutD, respectively). The other variants were obtained by PCR mutagenesis using the oligonucleotide pairs given in Table 1 and plasmid pUC18::T7-yU3A $\Delta 2,3,4$ as the matrix. This plasmid was generated by insertion of the PstI/EcoRI fragment of phages M13mp19::T7-yU3A $\Delta 2,3,4$ into plasmid pUC18 cleaved by the same enzymes.

For functional assays in the S. cerevisiae JH84 strain (Hughes and Ares 1991), the SalI-EcoRI DNA segment of plasmid pASZ11::yU3A, encoding the wild-type (WT) U3A snoRNA gene (Mereau et al. 1997) was substituted by the SalI-EcoRI DNA fragment from phage M13mp19::T7-yU3A $\Delta 2,3,4$ (plasmid pASZ11::yU3A $\Delta 2,3,4)$ or the SalI-EcoRI DNA fragment from 
TABLE 1. The oligonucleotides used in this study

\begin{tabular}{|c|c|c|}
\hline Oligonucleotide name & Oligonucleotide sequence & Use \\
\hline SNU13-5' & 5'-GGATCCAAATGTCTGCCCCAAACCCA-3' & PCR \\
\hline SNU13-3' & 5'-CTCGAGTTAAATTAATAAAGTTTCAATCTTG-3' & PCR \\
\hline $\mathrm{y} U 3 \mathrm{~A} \Delta 2,3,4$ & 5'-CСТTTGTACCCATAAGATCATCGCGTTTCTCACTCTGGGGTACAAAGG-3' & SDM \\
\hline $\mathrm{y} U 3 \mathrm{~A} \Delta 2,3,4$ mutB & 5'-TAAGATCATCGCGTTTGAGTGAGTGGGGTACAAAGGTTA-3' & SDM \\
\hline$y \cup 3 A \Delta 2,3,4$ mutD & 5'-AAAGTGGTTAACTTGAGACTGAGCCATTTGTACCCA-3' & SDM \\
\hline$y U 3 C / D-5$ & 5'-TAATACGACTCACTATAGGGACTTGGTTGATGATTCGT-3' & PCR \\
\hline YU3C'/D-3' & 5'-ACTTGTCAGACGAATC-3' & PCR \\
\hline $\mathrm{C}^{\prime} \mathrm{mut} \mathrm{U}_{2} \mathrm{~A}-\mathrm{y} \cup 3 \mathrm{C}^{\prime} / \mathrm{D}-5^{\prime}$ & 5'-TAATACGACTCACTATAGGGACTTGGATGATGATTCGT-3' & PCR \\
\hline $\mathrm{C}^{\prime} \mathrm{mutU}_{2} \mathrm{G}-\mathrm{y} U 3 \mathrm{C}^{\prime} / \mathrm{D}-5^{\prime}$ & 5'-TAATACGACTCACTATAGGGACTTGGGTGATGATTCGT-3' & PCR \\
\hline $\mathrm{C}^{\prime} \mathrm{mutU} \mathrm{H}_{2} \mathrm{C}-\mathrm{y} U 3 \mathrm{C}^{\prime} / \mathrm{D}-5^{\prime}$ & 5'-TAATACGACTCACTATAGGGACTTGGCTGATGATTCGT-3' & PCR \\
\hline$y \cup 3 B / C-5^{\prime}$ & 5'-TAATACGACTCACTATAGGGTACCCCAGAGTGAGAAAC-3' & PCR \\
\hline$y \cup 3 B / C-3^{\prime}$ & 5'-TAAATTTCAACCAGGGTACCCATAAGATCATCGC-3' & PCR \\
\hline $\mathrm{CmutA}_{2} \mathrm{U}-\mathrm{y} \cup 3 \mathrm{~A} \Delta 2,3,4-1$ & 5'-GTGAGAAACGCGTTGATCTTATGGG-3' & SDM \\
\hline $\mathrm{CmutA}_{2} \cup-\mathrm{y} \cup 3 \mathrm{~A} \Delta 2,3,4-2$ & 5'-CCCATAAGATCAACGCGTTTCTCAC-3' & SDM \\
\hline $\mathrm{CmutA}_{2} \mathrm{C}-\mathrm{y} U 3 \mathrm{~A} \Delta 2,3,4-1$ & 5'-GTGAGAAACGCGCTGATCTTATGGG-3' & SDM \\
\hline $\mathrm{CmutA}_{2} \mathrm{C}-\mathrm{y} \cup 3 \mathrm{~A} \Delta 2,3,4-2$ & 5'-CCCATAAGATCAGCGCGTTTCTCAC-3' & SDM \\
\hline $\mathrm{CmutA}_{2} \mathrm{G}-\mathrm{y} \cup 3 \mathrm{~A} \Delta 2,3,4-1$ & 5'-GTGAGAAACGCGGTGATCTTATGGG-3' & SDM \\
\hline $\mathrm{CmutA}_{2} \mathrm{G}-\mathrm{y} \cup 3 \mathrm{~A} \Delta 2,3,4-2$ & 5'-CCCATAAGATCACCGCGTTTCTCAC-3' & SDM \\
\hline $\mathrm{CmutU}_{3} \mathrm{~A}-\mathrm{y} \cup 3 \mathrm{~A} \Delta 2,3,4-1$ & 5'-GAGTGAGAAACGCGAAGATCTTATGGGTAC-3' & SDM \\
\hline $\mathrm{CmutU}_{3} \mathrm{~A}-\mathrm{y} \cup 3 \mathrm{~A} \Delta 2,3,4-2$ & 5'-GTACCCATAAGATCTTCGCGTTTCTCACTC-3' & SDM \\
\hline $\mathrm{CmutU}_{3} \mathrm{G}-\mathrm{y} \cup 3 \mathrm{~A} \Delta 2,3,4-1$ & 5'-GAGTGAGAAACGCGAGGATCTTATGGGTAC-3' & SDM \\
\hline $\mathrm{CmutU}_{3} \mathrm{G}-\mathrm{y} \cup 3 \mathrm{~A} \Delta 2,3,4-2$ & 5'-GTACCCATAAGATCCTCGCGTTTCTCACTC-3' & SDM \\
\hline $\mathrm{CmutU}_{3} \mathrm{C}-\mathrm{y} \cup 3 \mathrm{~A} \Delta 2,3,4-1$ & 5'-GAGTGAGAAACGCGACGATCTTATGGGTAC-3' & SDM \\
\hline $\mathrm{CmutU}_{3} \mathrm{C}-\mathrm{y} \cup 3 \mathrm{~A} \Delta 2,3,4-2$ & 5'-GTACCCATAAGATCGTCGCGTTTCTCACTC-3' & SDM \\
\hline $\mathrm{C}^{\prime}$ mutU $_{2} \mathrm{C}-\mathrm{y} \cup 3 \mathrm{~A} \Delta 2,3,4-1$ & 5'-CTGAATCCAACTTGGCTGATGAGTTCCATACC-3' & SDM \\
\hline $\mathrm{C}^{\prime} \mathrm{mut} \mathrm{U}_{2} \mathrm{C}-\mathrm{y} \cup 3 \mathrm{~A} \Delta 2,3,4-2$ & 5'-GTTATGGGAACTCATCAGCCAAGTTGGATTCAG-3' & SDM \\
\hline $\mathrm{C}^{\prime} \mathrm{mut}_{2} \mathrm{~A}-\mathrm{y} \cup 3 \mathrm{~A} \Delta 2,3,4-1$ & 5'-CTGAATCCAACTTGGATGATGAGTTCCCATAAC-3' & SDM \\
\hline $\mathrm{C}^{\prime} \mathrm{mut} \mathrm{U}_{2} \mathrm{~A}-\mathrm{y} U 3 \mathrm{~A} \Delta 2,3,4-2$ & 5'-GTTATGGGAACTCATCATCCAAGTTGGATTCAG-3' & SDM \\
\hline $\mathrm{C}^{\prime} \mathrm{mutU} \mathrm{U}_{2} \mathrm{G}-\mathrm{y} \cup 3 \mathrm{~A} \Delta 2,3,4-1$ & 5'-CTGAATCCAACTTGGGTGATGAGTTCCCATAAC-3' & SDM \\
\hline $\mathrm{C}^{\prime} \mathrm{mutU} \mathrm{U}_{2} \mathrm{G}-\mathrm{y} \cup 3 \mathrm{~A} \Delta 2,3,4-2$ & 5'-GTTATGGGAACTCATCACCCAAGTTGGATTCAG-3' & SDM \\
\hline $\mathrm{C}^{\prime} \mathrm{mutU} \mathrm{U}_{3} \mathrm{~A}-\mathrm{y} \cup 3 \mathrm{~A} \Delta 2,3,4-1$ & 5'-GAATCCAACTTGGTAGATGAGTCCCATAAC-3' & SDM \\
\hline $\mathrm{C}^{\prime} \mathrm{mutU}_{3} \mathrm{~A}-\mathrm{y} \cup 3 \mathrm{~A} \Delta 2,3,4-2$ & 5'-GTTATGGGACTCATCTACCAAGTTGGATTC-3' & SDM \\
\hline $\mathrm{C}^{\prime} \mathrm{mutU}_{3} \mathrm{G}-\mathrm{y} \cup 3 \mathrm{~A} \Delta 2,3,4-1$ & 5'-GAATCCAACTTGGTGGATGAGTCCCATAAC-3' & SDM \\
\hline $\mathrm{C}^{\prime} \mathrm{mutU} \mathrm{U}_{3} \mathrm{G}-\mathrm{y} \cup 3 \mathrm{~A} \Delta 2,3,4-2$ & 5'-GTTATGGGACTCATCCACCAAGTTGGATTC-3' & SDM \\
\hline $\mathrm{C}^{\prime} \mathrm{mutU}_{3} \mathrm{C}-\mathrm{y} \cup 3 \mathrm{~A} \Delta 2,3,4-1$ & 5'-GAATCCAACTTGGTCGATGAGTCCCATAAC-3' & SDM \\
\hline $\mathrm{C}^{\prime} \mathrm{mutU}_{3} \mathrm{C}-\mathrm{y} \cup 3 \mathrm{~A} \Delta 2,3,4-2$ & 5'-GTTATGGGACTCATCGACCAAGTTGGATTC-3' & SDM \\
\hline DmutGA-yU3A $\Delta 2,3,4-1$ & 5'-TGGGTACAAATGGCAGTCTCTGAAGTTAACCACTTTT-3' & SDM \\
\hline DmutGA-yU3A $\Delta 2,3,4-2$ & 5'-AAAGTGGTTAACTTGAGAGACTGCCATTTGTACCCA-3' & SDM \\
\hline$y \cup 3-5^{\prime}$ & 5'-AGCTCGTCGACGTACTTC-3 & PCR \\
\hline RT-yU3 & 5'-ACTTGTCAGACTGCC-3' & $\mathrm{PE}, \mathrm{NB}$ \\
\hline RT-yU6 & 5'-CAGGGGAACTGCTG-3' & NB \\
\hline hU3-5' & 5'-CAGGAAACAGCTATGAC-3' & PCR \\
\hline RT-hU3 & 5'-CTAATACGACTCACTATAGGG-3' & PE \\
\hline
\end{tabular}

variants pUC18::T7-yU3A $\Delta 2,3,4$, giving rise to recombinant plasmids pASZ11::yU3A $\Delta 2,3,4$ vCmutA2U, vCmutA2C, vCmutA2G, vCmutU3A, vCmutU3G, vCmutU3C, vC'mutU2A, vC'mutU2G, vC'mutU3A, vC'mutU3G, vC'mutU3C, vDmutGA.

\section{Preparation of DNA templates for in vitro transcription}

For production of the $\mathrm{yU} 3 \mathrm{C}^{\prime} / \mathrm{D}$ DNA template, partially complementary oligonucleotides ( $y U 3 \mathrm{C}^{\prime} / \mathrm{D}-5^{\prime}$ and $\mathrm{yU} 3 \mathrm{C}^{\prime} / \mathrm{D}-3^{\prime}$; Table 1) were annealed, and subjected to PCR amplification. For production of the $\mathrm{yU} 3 \mathrm{C}^{\prime} / \mathrm{D}$ variant RNAs, oligonucleotide $\mathrm{yU} 3 \mathrm{C}^{\prime} / \mathrm{D}-3^{\prime}$ was also used in combination with a series of oligonucleotides generating mutations in box $\mathrm{C}^{\prime}$ (oligonucleotides $\mathrm{C}^{\prime}$ mutU2A-5', $\mathrm{C}^{\prime}$ mutU2G-5', and $\mathrm{C}^{\prime}$ mutU2C-5'; Table 1). Templates for in vitro production of WT or variant $y \mathrm{U} 3 \mathrm{~B} / \mathrm{C}$ RNAs were obtained by PCR amplification with oligonucleotides $\mathrm{yU} 3 \mathrm{~B} / \mathrm{C}-5^{\prime}$ and $\mathrm{yU} 3 \mathrm{~B} / \mathrm{C}-3^{\prime}$ (Table 1), using as the matrices phage M13mp19::T7-yU3A $\Delta 2,3,4$ for the $\mathrm{WT} y \mathrm{H} 3 \mathrm{~B} / \mathrm{C}$ RNA template, and the variant pUC18::T7$\mathrm{yU} 3 \mathrm{~A} \Delta 2,3,4$ plasmids described above for the variant $\mathrm{yU} 3 \mathrm{~B} / \mathrm{C}$ CmutA2C, CmutA2U, CmutA2G, CmutU3A, CmutU3C, and CmutU3G RNA templates. For hU3 RNA production, a DNA fragment containing a SP6 promoter and the hU3 coding region was PCR amplified from plasmid pBS+SP6::hU3 using oligonucleotides hU3-5' and RT-hU3 (Table 1). For production of the $\mathrm{yU} 3 \mathrm{~A}, \mathrm{yU} 3 \mathrm{~A} \Delta 2,3,4, \mathrm{yU} 3 \mathrm{~A} \Delta 2,3,4 \mathrm{mutB}$, and $\mathrm{yU} 3 \mathrm{~A} \Delta 2,3,4 \mathrm{mutD}$ 
transcripts, the M13 phages encoding these RNAs were linearized with HpaI, that cleaves at the $3^{\prime}$ end of the U3 coding sequence (Segault et al. 1992).

\section{In vitro transcription}

For structural analysis, cold RNA transcripts were produced by transcription of phage M13mp9::T7-snR17A and its derivatives with the T7 RNA polymerase, using the conditions previously described (Mougin et al. 1996), or by transcription of the hU3 PCR matrix with the SP6 RNA polymerase, using the conditions described by Fischer et al. (1991). For electrophoretic mobility shift-assays (EMSA), uniformly labeled RNAs were produced by transcription of linearized phage DNAs or PCR DNA fragments with T7 RNA polymerase. Transcriptions were carried out on about $1 \mu \mathrm{g}$ of linearized phage DNA or about $500 \mathrm{ng}$ of PCR product, in a $15 \mu \mathrm{L}$ reaction mixture containing $20 \mathrm{mM} \mathrm{MgCl}_{2} ; 40$ $\mathrm{mM}$ Tris HCl, pH 8; 5 mM DTT; 1 mM Spermidine; 0.01\% Triton $\mathrm{X}-100 ; 80 \mathrm{mg} / \mathrm{mL}$ PEG $8000 ; 36 \mathrm{U}$ of RNasine (Amersham); $2 \mathrm{mM}$ of rATP, rCTP, and rGTP; $0.1 \mathrm{mM}$ UTP, $25 \mu \mathrm{Ci}$ of $\left[\alpha-{ }^{32} \mathrm{P}\right] \mathrm{UTP}$ $(800 \mathrm{Ci} / \mathrm{mmol})(\mathrm{ICN})$; and $40 \mathrm{U}$ of T7 RNA polymerase (USB Pharmacia Biotech). Incubation and subsequent treatments of RNAs were done as previously described (Mougin et al. 1996).

\section{Chemical probing of RNA and RNA/protein complexes and primer extension analysis}

For RNA/protein complex formation, about 20 fmoles of in vitro transcribed yU3A $\Delta 2,3,4$ RNA or yU3A, or 15 fmoles of hU3 RNA were incubated $30 \mathrm{~min}$ at $4^{\circ} \mathrm{C}$ with 60 pmoles of the recombinant Snu13 protein or 50 pmoles of the recombinant $15.5-\mathrm{kD}$ protein, respectively (which correspond to [RNA]/[protein] ratios of $1 / 3000$ and $1 / 3300$, respectively), and $2 \mu \mathrm{g}$ of yeast tRNA mixture, in $10 \mu \mathrm{L}$ of buffer D (150 mM KCl; $1.5 \mathrm{mM} \mathrm{MgCl}_{2} ; 0.2 \mathrm{mM}$ EDTA; $20 \mathrm{mM}$ HEPES, $\mathrm{pH}$ 7.9). Prior to the chemical reaction, the volume and composition of the solution were adjusted, so that the RNA/protein complex or free RNA was in $40 \mu \mathrm{L}$ of chemical reagent buffer. After a 10 -min incubation at $20^{\circ} \mathrm{C}$, the chemical reagent was added. DMS and kethoxal modifications were performed in $\left(100 \mathrm{mM} \mathrm{KCl} ; 2.5 \mathrm{mM} \mathrm{MgCl}_{2} ; 50 \mathrm{mM}\right.$ sodium cacodylate, $\mathrm{pH} 7.5)$, with $1 \mu \mathrm{L}$ of a DMS solution (1/4 [v/v]; DMS/ $\mathrm{EtOH})$ or $148 \mu \mathrm{g}$ of kethoxal per assay. CMCT modifications were made in (100 mM KCl; $2.5 \mathrm{mM} \mathrm{MgCl}_{2} ; 50 \mathrm{mM}$ sodium borate, $\mathrm{pH}$ 8), with $3.36 \mathrm{mg}$ of CMCT per assay. For all reagents, incubation was for $6 \mathrm{~min}$ at $20^{\circ} \mathrm{C}$. All chemical reactions were stopped by phenol-chloroform extraction and ethanol precipitation. For the DMS reactions, $10 \mu \mathrm{L}$ of DMS stop buffer (1.5 M sodium acetate; $1 \mathrm{M} \beta$-mercaptoethanol; 0.1 mM EDTA; $1 \mathrm{M}$ Tris-acetate, $\mathrm{pH}$ 7.5) were added prior to phenol extraction. For kethoxal reactions, 10 $\mu \mathrm{L}$ of $0.5 \mathrm{M}$ potassium borate, $\mathrm{pH} 7$ were added, prior to phenol extraction. Primer extension analyses were performed as previously described (Mougin et al. 1996) with the Avian Myeloblastosis Virus Reverse Transcriptase (Q BIOgene) and the 5'-labeled RT-hU3 or RT-yU3 (Table 1). Chemical probing of naked RNA was performed in the same conditions with preincubation $30 \mathrm{~min}$ at $4^{\circ} \mathrm{C}$ without addition of protein, followed by dilution and a 10 min incubation at $20^{\circ} \mathrm{C}$, prior to chemical reagent addition.

\section{Comparative analysis of U3 snoRNAs from various species}

The snoRNA sequences used in the comparison correspond to the following references in GenBank: Homo sapiens: AF020531; Mus musculus: X04258; Xenopus laevis: Z12613; Tomato (Lycopersicon esculentum): X14411; wheat (Triticum aestivum): X63065; Chlamydomonas reinhardtii: AJ001179; Euglena gracilis: U27297; Crithidia fasciculata: AF277396; Tetrahymena thermophila: X71349; Schyzosaccharomyces pombe: X56982; Saccharomyces cerevisiae: X91037; Hansenula wingei: X91005; Kluyveromyces marxianus var. bulgaricus: Y14752; Kluyveromyces delphensis: Z78432; Kluyveromyces marxianus var.fragilis: Y14751; Kluyveromyces marxianus var.lactis: X87402. For the Trypanosoma brucei U3 snoRNA, that was not referred to GenBank, the sequence was taken from Hartshorne and Toyofuku (1999). The Pichia U3 snoRNA genes were sequenced after their PCR amplification from genomic DNA with oligonucleotide primers RT-yU3 and yU3-5' (Table 1), in the conditions previously described (Fournier et al. 1998), and their references in GenBank are: Pichia anomala: AJ507111; Pichia guilliermondii: AJ507112; Pichia pastoris: AJ507113; Pichia salictaria: AJ507109.

\section{Electrophoretic mobility shift assay}

About 5 fmoles of ${ }^{32} \mathrm{P}$-labeled in vitro transcribed RNA, mixed with $10 \mu \mathrm{g}$ of yeast tRNA (Roche), were heat denatured $10 \mathrm{~min}$ at $65^{\circ} \mathrm{C}$, in $15 \mu \mathrm{L}$ of buffer $\mathrm{D}$. This denaturing step was followed by slow cooling to room temperature for renaturation. The Snu13 recombinant protein, was added at various concentrations comprised between 0 and $4000 \mathrm{nM}$, so that the RNA/protein concentration was comprised between 0 and $1 / 12000$, and the mixture was incubated for $30 \mathrm{~min}$ at $4^{\circ} \mathrm{C}$. The RNA-protein complexes formed were subsequently resolved in a $6 \%(38 / 2)$ nondenaturing polyacrylamide gel containing $44.5 \mathrm{mM}$ borate; $1 \mathrm{mM}$ EDTA; 44.5 mM Tris-borate, $\mathrm{pH} 8.3$ and 5\% glycerol.

\section{Test of the U3 snoRNA variant expression and stability}

The stability of WT and variant U3 snoRNAs were compared using Northern blot analysis after electrophoresis on a $6 \%$ polyacrylamide denaturing gel as described previously (Mereau et al. 1997). The 5'-end labeled oligonucleotide RT-yU3 (Table 1), complementary to the $3^{\prime}$-end of the yeast U3 snoRNA was used as the probe, and the $5^{\prime}$-end labeled RT-yU6 oligonucleotide (Table 1), complementary to U6 snRNA was used for standardization of the data. Data are expressed as the ratio between the radioactivity found in the WT or variant U3 snoRNA band and that in the U6 snRNA band.

The radioactivities in these bands were quantified with a Molecular Dynamic Phospho Imager using the Image Quant software.

\section{Test of the U3 snoRNA variant functionality}

The S. cerevisiae strain JH84 was transformed with plasmid pASZ11, pASZ11::yU3A, pASZ11::yU3A $\Delta 2,3,4$ and its derivatives (vCmutA2U, vCmutA2C, vCmutA2G, vCmutU3A, vCmutU3G, vCmutU3C, vC'mutU2A, vC'mutU2G, vC'mutU3A, 
vC'mutU3G, vC'mutU3C, vDmutGA), using the Li-Acetate method (Gietz et al. 1992). Selection of transformants was made on minimum medium plates. Recombinant JH84 cells were first grown for $48 \mathrm{~h}$ at $30^{\circ} \mathrm{C}$ in YPG liquid medium. After centrifugation and washing in YPD medium, the cells were transferred in liquid YPD medium, and grown for $24 \mathrm{~h}$ at $30^{\circ} \mathrm{C}$. Then, growth was tested on YPD plates at three temperatures $\left(20^{\circ} \mathrm{C}, 30^{\circ} \mathrm{C}\right.$, and $37^{\circ} \mathrm{C}$ ). Sizes of colonies were examined after $48 \mathrm{~h}$ of incubation at $30^{\circ} \mathrm{C}$ and $37^{\circ} \mathrm{C}$, or after $72 \mathrm{~h}$ of incubation at $20^{\circ} \mathrm{C}$.

\section{ACKNOWLEDGMENTS}

Professor R. Lührmann from the Max Planck Institute of Göttingen is thanked for his generous gift of purified recombinant 15.5$\mathrm{kD}$ protein and of the $\mathrm{pBS}+\mathrm{SP} 6: \mathrm{hU} 3$ plasmid used for in vitro transcription of human U3 snoRNA. Dr. Fukuhara from the Institut Curie at Orsay is thanked for providing us with the four Pichia strains used in this study. Dr. Mc Rae is thanked for careful reading of this manuscript. N. Marmier-Gourrier and A. Cléry were fellows of French Ministère de la Jeunesse, de l'Education Nationale et de la Recherche. This work was financially supported by the Centre National de la Recherche Scientifique and the French Ministère de la Jeunesse, de l'Education Nationale et de la Recherche.

The publication costs of this article were defrayed in part by payment of page charges. This article must therefore be hereby marked "advertisement" in accordance with 18 USC section 1734 solely to indicate this fact.

Received August 29, 2002; accepted March 28, 2003.

\section{REFERENCES}

Beltrame, M. and Tollervey, D. 1992. Identification and functional analysis of two U3 binding sites on yeast pre-ribosomal RNA. EMBO J. 11: 1531-1542.

- 1995. Base pairing between U3 and the pre-ribosomal RNA is required for 18S rRNA synthesis. EMBO J. 14: 4350-4356.

Beltrame, M., Henry, Y., and Tollervey, D. 1994. Mutational analysis of an essential binding site for the U3 snoRNA in the $5^{\prime}$ external transcribed spacer of yeast pre-rRNA. Nucleic Acids Res. 22: 51395147.

Borovjagin, A.V. and Gerbi, S.A. 1999. U3 small nucleolar RNA is essential for cleavage at sites 1,2 and 3 in pre-rRNA and determines which rRNA processing pathway is taken in Xenopus oocytes. J. Mol. Biol. 286: 1347-1363.

- 2000. The spacing between functional cis-elements of U3 snoRNA is critical for rRNA processing. J. Mol. Biol. 300: 57-74.

- 2001. -Xenopus U3 snoRNA GAC-Box A' and Box A sequences play distinct functional roles in rRNA processing. Mol. Cell Biol. 21: 6210-6221.

Brule, F., Venema, J., Segault, V., Tollervey, D., and Branlant, C. 1996. The yeast Hansenula wingei U3 snoRNA gene contains an intron and its coding sequence co-evolved with the $5^{\prime}$ ETS region of the pre-ribosomal RNA. RNA 2: 183-197.

Cahill, N.M., Friend, K., Speckmann, W., Li, Z.H., Terns, R.M., Terns, M.P., and Steitz, J.A. 2002. Site-specific cross-linking analyses reveal an asymmetric protein distribution for a box C/D snoRNP. EMBO J. 21: 3816-3828.

Cavaille, J., Nicoloso, M., and Bachellerie, J.P. 1996. Targeted ribose methylation of RNA in vivo directed by tailored antisense RNA guides. Nature 383: 732-735.

Darzacq, X. and Kiss, T. 2000. Processing of intron-encoded box C/D small nucleolar RNAs lacking a 5',3' -terminal stem structure. Mol. Cell Biol. 20: 4522-4531.

Fischer, U., Darzynkiewicz, E., Tahara, S.M., Dathan, N.A., Luhrmann, R., and Mattaj, I.W. 1991. Diversity in the signals required for nuclear accumulation of $U$ snRNPs and variety in the pathways of nuclear transport. J. Cell. Biol. 113: 705-714.

Fournier, R., Brule, F., Segault, V., Mougin, A., and Branlant, C. 1998. $\mathrm{U} 3$ snoRNA genes with and without intron in the Kluyveromyces genus: Yeasts can accommodate great variations of the U3 snoRNA 3'-terminal domain. RNA 4: 285-302.

Ganot, P., Bortolin, M.L., and Kiss, T. 1997. Site-specific pseudouridine formation in preribosomal RNA is guided by small nucleolar RNAs. Cell 89: 799-809.

Gautier, T., Berges, T., Tollervey, D., and Hurt, E. 1997. Nucleolar KKE/D repeat proteins Nop56p and Nop58p interact with Nop1p and are required for ribosome biogenesis. Mol. Cell Biol. 17: 70887098.

Gietz, D., St. Jean, A., Woods, R.A., and Schiestl, R.H. 1992. Improved method for high efficiency transformation of intact yeast cells. Nucleic Acids Res. 20: 1425.

Gottschalk, A., Neubauer, G., Banroques, J., Mann, M., Luhrmann, R., and Fabrizio, P. 1999. Identification by mass spectrometry and functional analysis of novel proteins of the yeast [U4/U6.U5] trisnRNP. EMBO J. 18: 4535-4548.

Granneman, S., Pruijn, G.J., Horstman, W., Van Venrooij, W.J., Luhrmann, R., and Watkins, N.J. 2002. The hU3-55K Protein requires $15.5 \mathrm{~K}$ binding to the box $\mathrm{B} / \mathrm{C}$ motif as well as flanking RNA elements for its association with the U3 small nucleolar RNA in vitro. J. Biol. Chem. 277: 48490-48500.

Hartshorne, T. and Toyofuku, W. 1999. Two 5'-ETS regions implicated in interactions with U3 snoRNA are required for small subunit rRNA maturation in Trypanosoma brucei. Nucleic Acids Res. 27: 3300-3309.

Hughes, J.M. 1996. Functional base-pairing interaction between highly conserved elements of U3 small nucleolar RNA and the small ribosomal subunit RNA. J. Mol. Biol. 259: 645-654.

Hughes, J.M. and Ares Jr., M. 1991. Depletion of U3 small nucleolar RNA inhibits cleavage in the $5^{\prime}$ external transcribed spacer of yeast pre-ribosomal RNA and impairs formation of $18 \mathrm{~S}$ ribosomal RNA. EMBO J. 10: 4231-4239.

Hughes, J.M., Konings, D.A., and Cesareni, G. 1987. The yeast homologue of U3 snRNA. EMBO J. 6: 2145-2155.

Jeppesen, C., Stebbins-Boaz, B., and Gerbi, S.A. 1988. Nucleotide sequence determination and secondary structure of Xenopus U3 snRNA. Nucleic Acids Res. 16: 2127-2148.

Klein, D.J., Schmeing, T.M., Moore, P.B., and Steitz, T.A. 2001. The kink-turn: A new RNA secondary structure motif. EMBO J. 20: $4214-4221$.

Kramer, W., Drutsa, V., Jansen, H.W., Kramer, B., Pflugfelder, M., and Fritz, H.J. 1984. The gapped duplex DNA approach to oligonucleotide-directed mutation construction. Nucleic Acids Res. 12: 94419456.

Lafontaine, D.L. and Tollervey, D. 1999. Nop58p is a common component of the box $\mathrm{C}+\mathrm{D}$ snoRNPs that is required for snoRNA stability. RNA 5: 455-467.

. 2000. Synthesis and assembly of the box C+D small nucleolar RNPs. Mol. Cell Biol. 20: 2650-2659.

Lange, T.S., Ezrokhi, M., Borovjagin, A.V., Rivera-Leon, R., North, M.T., and Gerbi, S.A. 1998. Nucleolar localization elements of Xenopus laevis U3 small nucleolar RNA. Mol. Biol. Cell 9: 29732985.

Lubben, B., Marshallsay, C., Rottmann, N., and Luhrmann, R. 1993. Isolation of U3 snoRNP from CHO cells: A novel $55 \mathrm{kDa}$ protein binds to the central part of U3 snoRNA. Nucleic Acids Res. 21: 5377-5385.

Lukowiak, A.A., Granneman, S., Mattox, S.A., Speckmann, W.A., Jones, K., Pluk, H., Venrooij, W.J., Terns, R.M., and Terns, M.P. 2000. Interaction of the U3-55k protein with U3 snoRNA is mediated by the box B/C motif of U3 and the WD repeats of U3-55k. 
Nucleic Acids Res. 28: 3462-3471.

Mereau, A., Fournier, R., Gregoire, A., Mougin, A., Fabrizio, P., Luhrmann, R., and Branlant, C. 1997. An in vivo and in vitro structurefunction analysis of the Saccharomyces cerevisiae U3A snoRNP: Protein-RNA contacts and base-pair interaction with the pre-ribosomal RNA. J. Mol. Biol. 273: 552-571.

Mougin, A., Gregoire, A., Banroques, J., Segault, V., Fournier, R., Brule, F., Chevrier-Miller, M., and Branlant, C. 1996. Secondary structure of the yeast Saccharomyces cerevisiae pre-U3A snoRNA and its implication for splicing efficiency. RNA 2: 1079-1093.

Mougin, A., Gottschalk, A., Fabrizio, P., Luhrmann, R., and Branlant, C. 2002. Direct probing of RNA structure and RNA-protein interactions in purified HeLa cell's and yeast spliceosomal U4/U6.U5 tri-snRNP particles. J. Mol. Biol. 317: 631-649.

Narayanan, A., Speckmann, W., Terns, R., and Terns, M.P. 1999. Role of the box C/D motif in localization of small nucleolar RNAs to coiled bodies and nucleoli. Mol. Biol. Cell 10: 2131-2147.

Ni, J., Tien, A.L., and Fournier, M.J. 1997. Small nucleolar RNAs direct site-specific synthesis of pseudouridine in ribosomal RNA. Cell 89: 565-573.

Nottrott, S., Hartmuth, K., Fabrizio, P., Urlaub, H., Vidovic, I., Ficner, R., and Luhrmann, R. 1999. Functional interaction of a novel $15.5 \mathrm{kD}$ [U4/U6.U5] tri-snRNP protein with the $5^{\prime}$ stem-loop of U4 snRNA. EMBO J. 18: 6119-6133.

Parker, K.A. and Steitz, J.A. 1987. Structural analysis of the human U3 ribonucleoprotein particle reveal a conserved sequence available for base pairing with pre-rRNA. Mol. Cell Biol. 7: 2899-2913.

Pluk, H., Soffner, J., Luhrmann, R., and van Venrooij, W.J. 1998. cDNA cloning and characterization of the human U3 small nucleolar ribonucleoprotein complex-associated 55-kilodalton protein. Mol. Cell Biol. 18: 488-498.

Samarsky, D.A. and Fournier, M.J. 1998. Functional mapping of the U3 small nucleolar RNA from the yeast Saccharomyces cerevisiae. Mol. Cell Biol. 18: 3431-3444.

Segault, V., Mougin, A., Gregoire, A., Banroques, J., and Branlant, C. 1992. An experimental study of Saccharomyces cerevisiae U3 snRNA conformation in solution. Nucleic Acids Res. 20: 3443-3451.

Speckmann, W.A., Terns, R.M., and Terns, M.P. 2000. The box C/D motif directs snoRNA 5'-cap hypermethylation. Nucleic Acids Res. 28: 4467-4473.

Stevens, S.W. and Abelson, J. 1999. Purification of the yeast U4/U6.U5 small nuclear ribonucleoprotein particle and identification of its proteins. Proc. Natl. Acad. Sci. 96: 7226-7231.

Szewczak, L.B., DeGregorio, S.J., Strobel, S.A., and Steitz, J.A. 2002. Exclusive interaction of the $15.5 \mathrm{kD}$ protein with the terminal box $\mathrm{C} / \mathrm{D}$ motif of a methylation guide snoRNP. Chem. Biol. 9: 1095-1107.

Terns, M.P. and Dahlberg, J.E. 1994. Retention and 5' cap trimethylation of U3 snRNA in the nucleus. Science 264: 959-961.

Terns, M.P. and Terns, R.M. 2002. Small nucleolar RNAs: Versatile trans-acting molecules of ancient evolutionary origin. Gene Expr. 10: $17-39$.

Tycowski, K.T., Shu, M.D., and Steitz, J.A. 1993. A small nucleolar RNA is processed from an intron of the human gene encoding ribosomal protein S3. Genes \& Dev. 7: 1176-1190.

Venema, J. and Tollervey, D. 1999. Ribosome synthesis in Saccharomyces cerevisiae. Annu. Rev. Genet. 33: 261-311.

Venema, J., Vos, H.R., Faber, A.W., van Venrooij, W.J., and Raue, H.A. 2000. Yeast Rrp9p is an evolutionarily conserved U3 snoRNP protein essential for early pre-rRNA processing cleavages and requires box C for its association. RNA 6: 1660-1671.

Verheggen, C., Lafontaine, D.L., Samarsky, D., Mouaikel, J., Blanchard, J.M., Bordonne, R., and Bertrand, E. 2002. Mammalian and yeast U3 snoRNPs are matured in specific and related nuclear compartments. EMBO J. 21: 2736-2745.

Vidovic, I., Nottrott, S., Hartmuth, K., Luhrmann, R., and Ficner, R. 2000. Crystal structure of the spliceosomal $15.5 \mathrm{kD}$ protein bound to a U4 snRNA fragment. Mol. Cell 6: 1331-1342.

Villa, T., Ceradini, F., and Bozzoni, I. 2000. Identification of a novel element required for processing of intron-encoded box C/D small nucleolar RNAs in Saccharomyces cerevisiae. Mol. Cell Biol. 20: $1311-1320$.

Watkins, N.J., Newman, D.R., Kuhn, J.F., and Maxwell, E.S. 1998. In vitro assembly of the mouse U14 snoRNP core complex and identification of a $65-\mathrm{kDa}$ box C/D-binding protein. RNA 4: 582-593.

Watkins, N.J., Segault, V., Charpentier, B., Nottrott, S., Fabrizio, P., Bachi, A., Wilm, M., Rosbash, M., Branlant, C., and Luhrmann, R. 2000. A common core RNP structure shared between the small nucleoar box C/D RNPs and the spliceosomal U4 snRNP. Cell 103: $457-466$.

Watkins, N.J., Dickmanns, A., and Luhrmann, R. 2002. Conserved stem II of the box C/D motif is essential for nucleolar localization and is required, along with the $15.5 \mathrm{~K}$ protein, for the hierarchical assembly of the box C/D snoRNP. Mol. Cell Biol. 22: 8342-8352.

Wise, J.A. and Weiner, A.M. 1980. Dictyostelium small nuclear RNA D2 is homologous to rat nucleolar RNA U3 and is encoded by a dispersed multigene family. Cell 22: 109-118.

Wu, P., Brockenbrough, J.S., Metcalfe, A.C., Chen, S., and Aris, J.P. 1998. Nop5p is a small nucleolar ribonucleoprotein component required for pre-18 S rRNA processing in yeast. J. Biol. Chem. 273: $16453-16463$ 

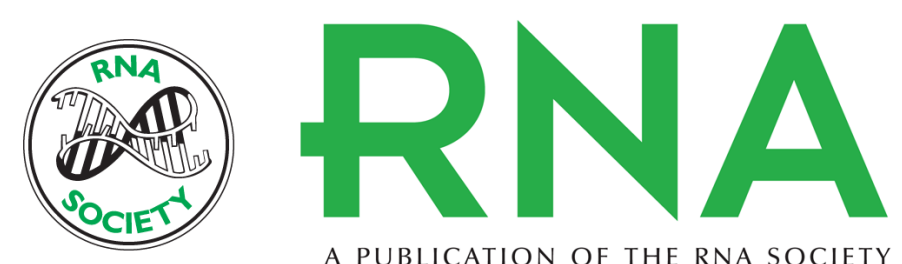

A PUBLICATION OF THE RNA SOCIETY

\section{A structural, phylogenetic, and functional study of 15.5-kD/Snu13 protein binding on U3 small nucleolar RNA}

NATHALIE MARMIER-GOURRIER, ANTOINE CLÉRY, VÉRONIQUE SENTY-SÉGAULT, et al.

RNA 2003 9: 821-838

References This article cites 55 articles, 27 of which can be accessed free at:

http://rnajournal.cshlp.org/content/9/7/821.full.html\#ref-list-1

\section{License}

Email Alerting Receive free email alerts when new articles cite this article - sign up in the box at Service the top right corner of the article or click here.

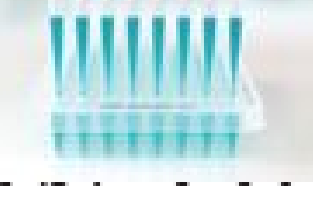

\section{Providing Precise Solutions for} your research.

To subscribe to RNA go to:

http://rnajournal.cshlp.org/subscriptions 